\title{
PROJECT RIO BLANCO \\ RADIOACTIVITY \\ AND THE ENVIRONMENT
}

March 3, 1975

\section{NOTICE}

\section{MASTER}

This report was prepared as an account of work sponsored by the United States Government. Neither the United States nor the United States Energy Research and Development Administration, nor any of their employees, nor any of their contractors, subcontractors, or their employees, makes any wabcontractors, or their employees, makes any liability of responsibility for the accuracy, completeness or usefulness of any information, apparatus, product or process disclosed, or represents that its use would not infringe privately owned rights. 


\section{DISCLAIMER}

This report was prepared as an account of work sponsored by an agency of the United States Government. Neither the United States Government nor any agency Thereof, nor any of their employees, makes any warranty, express or implied, or assumes any legal liability or responsibility for the accuracy, completeness, or usefulness of any information, apparatus, product, or process disclosed, or represents that its use would not infringe privately owned rights. Reference herein to any specific commercial product, process, or service by trade name, trademark, manufacturer, or otherwise does not necessarily constitute or imply its endorsement, recommendation, or favoring by the United States Government or any agency thereof. The views and opinions of authors expressed herein do not necessarily state or reflect those of the United States Government or any agency thereof. 


\section{DISCLAIMER}

Portions of this document may be illegible in electronic image products. Images are produced from the best available original document. 


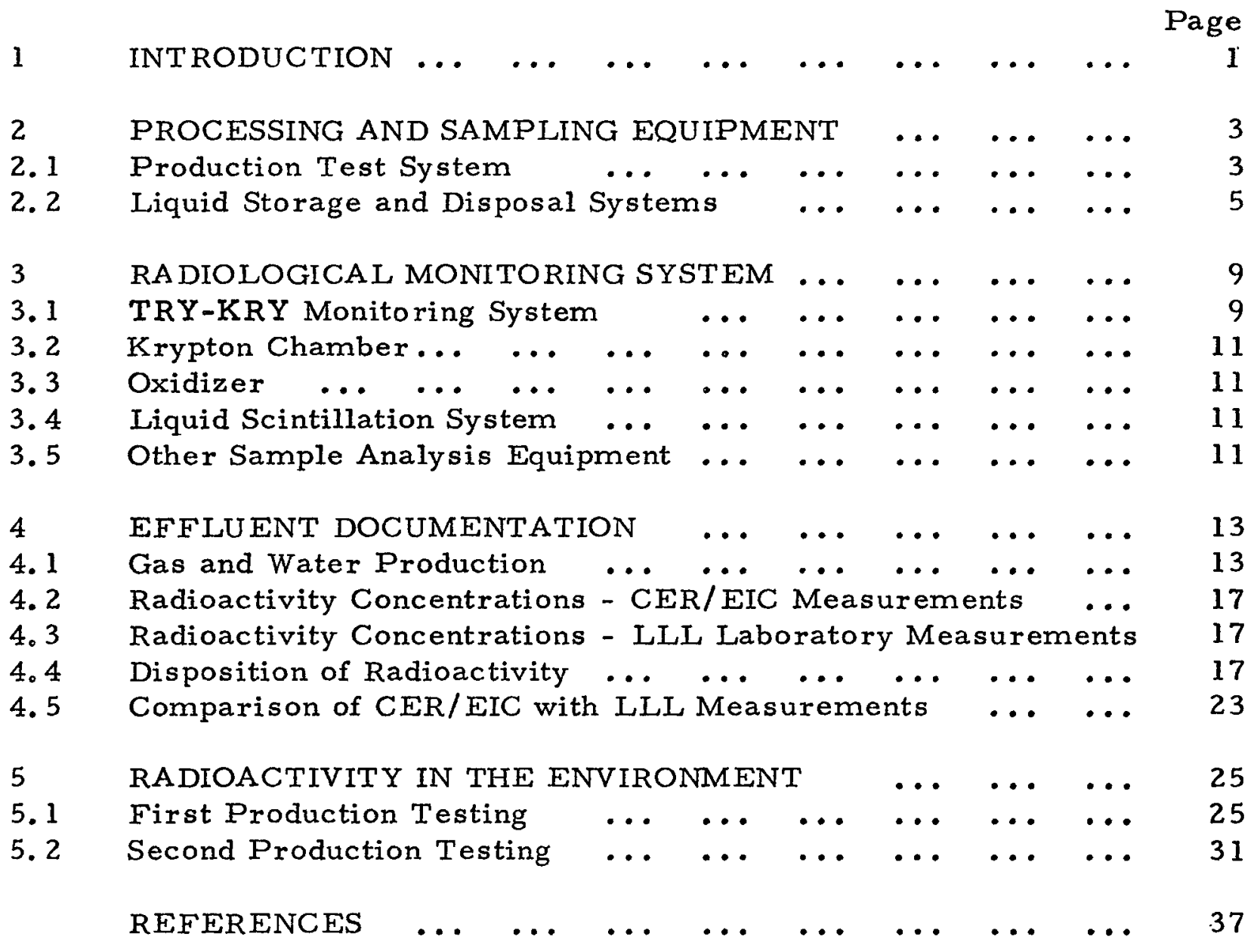


1. Effluent Release and Disposal Points, Project Rio Blanco Production Testing (S14, T3S, R98W, Colo.) ... ... ... 2

2. Project Rio Blanco Production Test System ... . . . . . . 4

3. Project Rio Blanco Liquid Storage and Disposal Systems ... . 6

4. As-Built Downhole Completion Detail, Fawn Creek Government

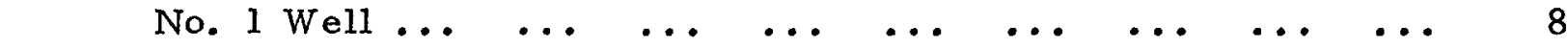

5. Production Test Gas Sampling System _.. $\ldots \ldots \ldots$... . . 10

6. Gas Sample Data From CER/EIC Field Measurements _.. 19

7. Gas Sample Data From LLL Laboratory Measurements ... 21

8. Close-In Environmental Monitoring Points - Production Testing 26

9. Distant Environmental Monitoring Points - Production Testing 29

10. ${ }^{3} \mathrm{H}$ Analysis Results, Feb. 15, 16, 1974, Vicinity of Flare

Stack ... ... ... ... ...

\section{TABLES}

1. Gas and Water Production $\ldots \ldots$...

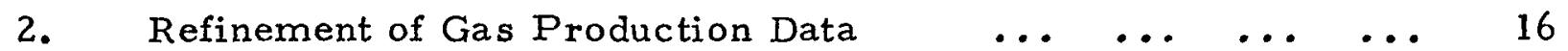

3. Field Measurements of Radionuclide Concentrations ... ... 18

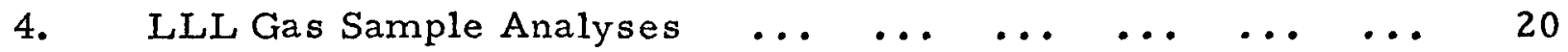

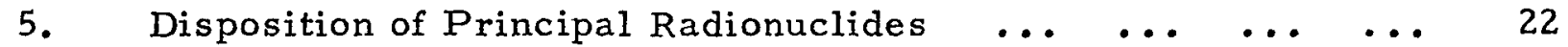

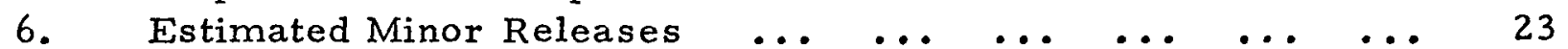

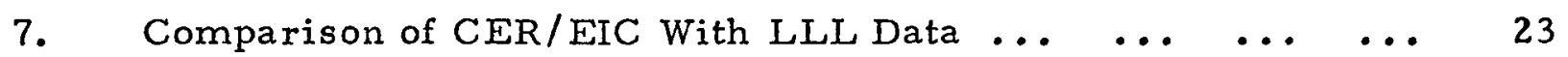

8. Site Air Moisture and Precipitation Samples, First Production

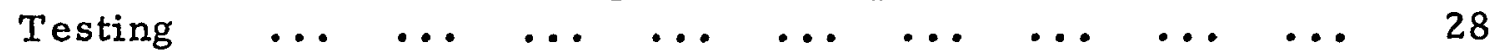

9. Site Air Moisture Samples, Second Production Testing _.. 32

10. ${ }^{3} \mathrm{H}$ Concentrations in Precipitation and Soils Near Flare Stack, Second Production Testing $\ldots \ldots \ldots \ldots \ldots$ 


\section{INTRODUCTION}

This report presents the results of measurement of releases of radioactivity to the environment in connection with the drawdown testing of the upper chimney created by the Project Rio Blanco nuclear gas stimulation experiment in the emplacement well, RB-E-01. It also includes the data obtained in radiological measurements of the environment and in documenting the transfer to a subsurface disposal well of tritiated water separated during production of gas.

The three nuclear explosives for Project Rio Blanco were detonated at 1000:00.12 \pm 0.01 second, Mountain Daylight Time, or 1600:00.12士0.01 second, Greenwich Mean Time, on May 17, 1973. The three explosions occurred within the Fort Union and Mesaverde formations at depths of 5,838. 5 feet, $6,229.7$ feet, and 6,689.5 feet. The three explosions occurred nearly simultaneously as planned and were completely contained. The preliminary indications are that the yields of the three explosives totalled approximately $90 \mathrm{kt}$. The elevation of the ground at the emplacement well, RB-E-01, is 6.629.9 feet above mean sea level. RB-E-01 is located $1,080.50$ feet south of the north line and 1, 188. 49 feet east of the west line in Section 14, Township 3 South, Range 98 West of 6 th P. M., Rio Blanco County, Colorado, which corresponds to geodetic coordinates of $108^{\circ} 21^{\prime} 59^{\prime \prime}$ west longitude and $39^{\circ} 47^{\prime} 35^{\prime \prime}$ north latitude.

The location of the emplacement well, RB-E-01, is shown in Figure 1, which includes an inset showing the relative location of the emplacement well, the stack from which the produced gas was flared, the well used as a subsurface disposal well, and the perennial Fawn Creek. 


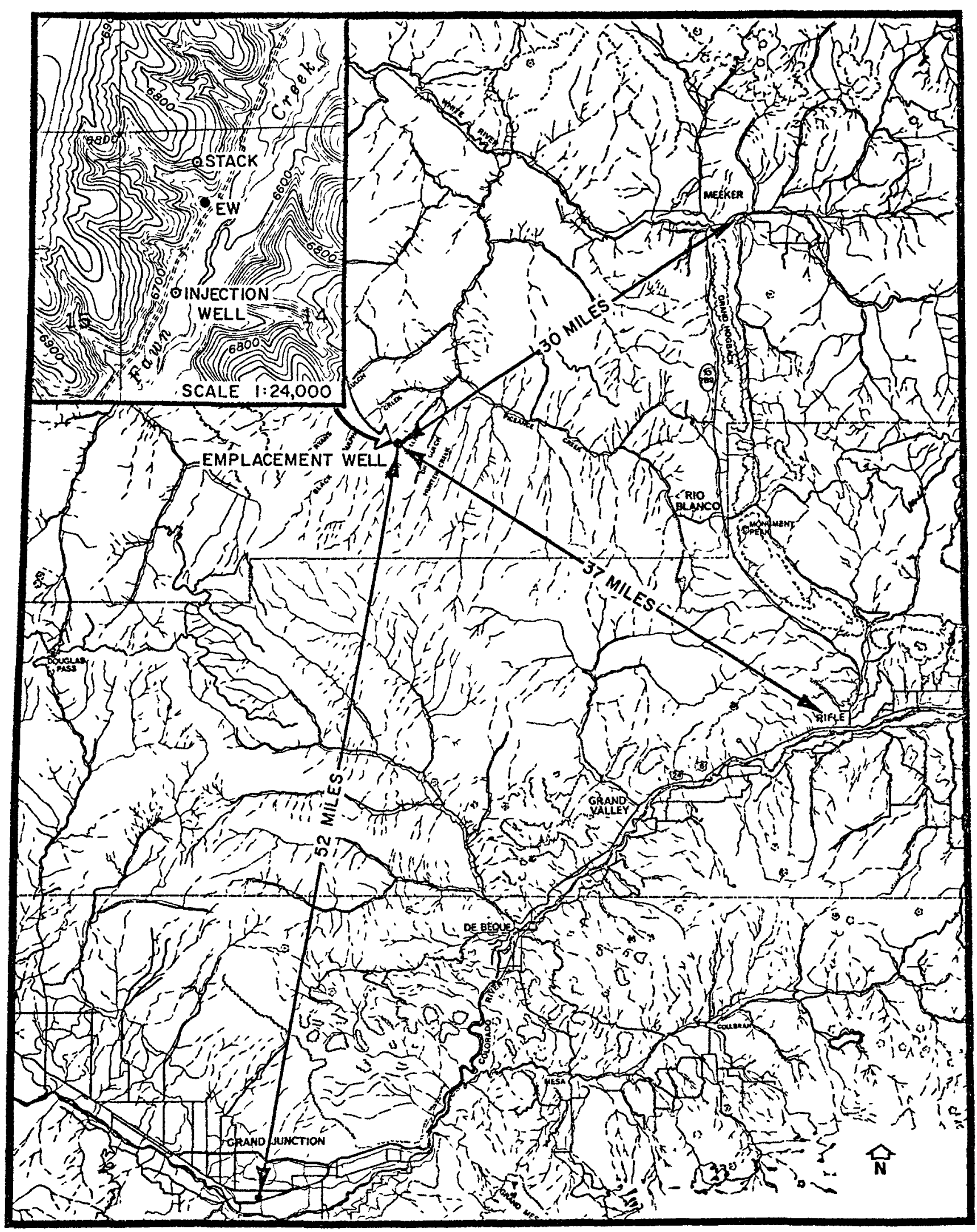

Figure 1. Effluent Release and Disposal Points, Project Rio Blanco Production Testing (In S14, T3S, R98W, Colo.). 


\section{PROCESSING AND SAMPLING EQUIPMENT}

Following the completion of reentry drilling into the upper chimney of the RB-E-01 well, the drill rig was removed and equipment installation completed for handling the gas and liquids to be produced from the well during two periods of drawdown tests. The first drawdown test period was from November 14 to November 20, 1973, and the second from January 28 to February 15, 1974.

\section{$2.1 \quad$ PRODUCTION TEST SYSTEM}

\subsubsection{Separator System}

The separator system (Figure 2) was a combination two-phase, high-pressure separator together with a three-phase, low-pressure separator. The system was designed to handle $30 \mathrm{MMSCFD}$ of gas and associated liquids at 1,000 psi and $300^{\circ} \mathrm{F}$. A heater was provided for use during startup to prevent hydrate formation. After the flowing gas temperature reached about $75{ }^{\circ} \mathrm{F}$, use of the heater was no longer required. Free liquid separated from the gas stream in the 1,500-psi working pressure separator was transferred to the 125-psi working pressure separator through a dump valve. The system had the capability of separating hydrocarbon condensates and water in the low-pressure separator for separate transfer through meters to their respective storage vessels. In practice, no measurable hydrocarbon condensates were found. A manual choke was provided just downstream of the high-pressure separator to control the pressure upstream of the meter run. The choke also provided a pressure drop which assured that the gas entering the meter run was undersaturated with water vapor.

\subsubsection{Meter Run}

Because the lead-time for procurement of the desired valve size was excessive, two meter runs in parallel were installed using smaller valves with appropriate orifice plates and pressure and temperature gauges (Figure 2). Orifice plate sizes were chosen so that the gas velocity through the orifices would be at the critical sonic velocity, at which the flow rate is independent of the downstream pressure. Corrections were made in the upstream pressure for variations in temperature and gas gravity to keep the flow rate at the desired value.

\subsubsection{Fin-Fan Coolers}

Three fin-fan coolers (Figure 2) were added to the production test system after the initial drawdown of the chimney pressure in order to reduce the temperature of the gas entering the separator to manageable levels. Temperatures in excess of $300^{\circ} . \mathrm{F}$ were observed in the November 1973 test period. Operation of the fin- 


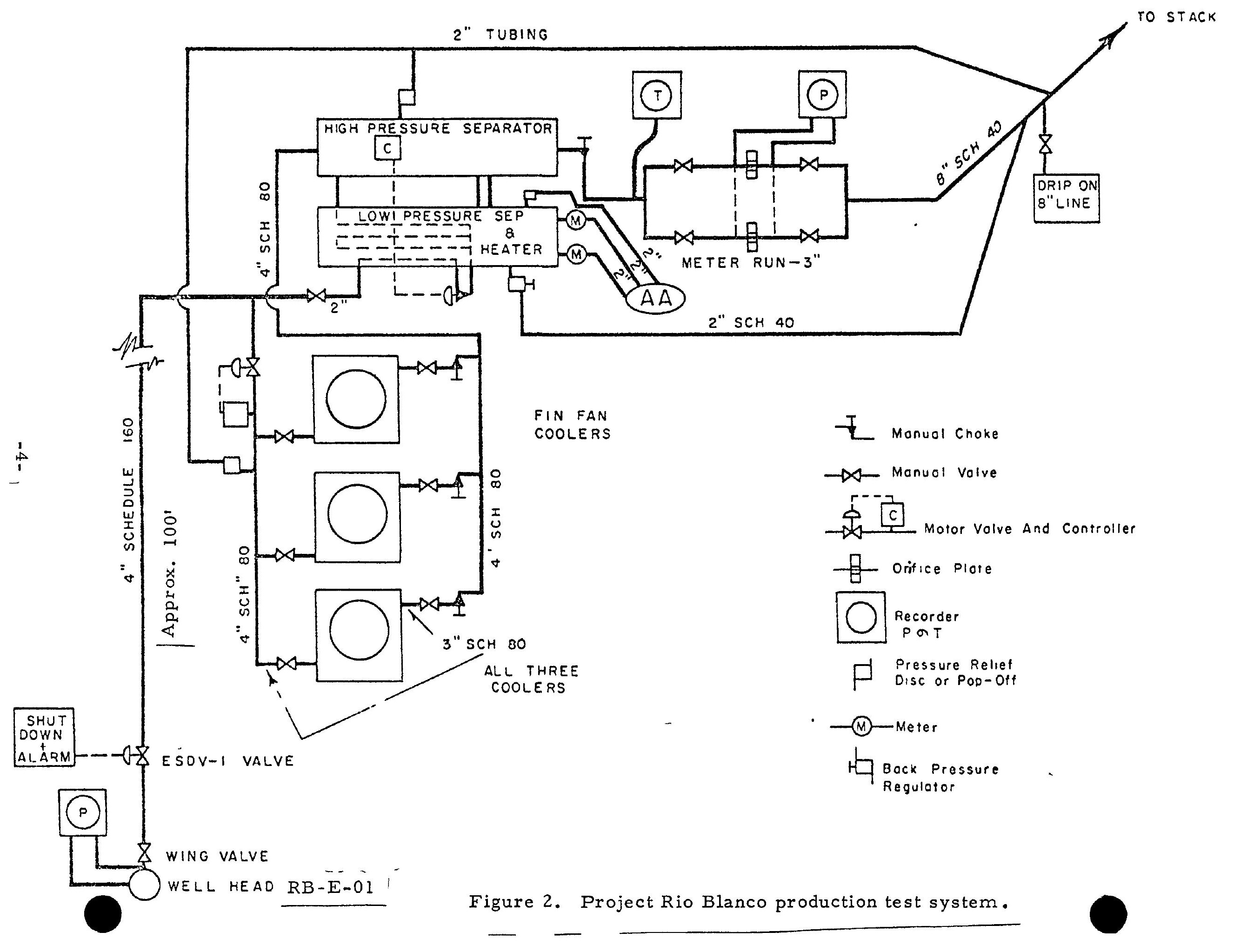


fan coolers in the January-February 1974 test period dropped the inlet temperature to the separator system to $150^{\circ} \mathrm{F}$ or less. A byproduct of this modification was a substantial reduction in the quantity of tritiated water vapor flared to the atmosphere.
2. 1.4
Flare Stack

The flare stack, located on a ridge about 600 feet north of and about 120 feet higher than the emplacement well (Figure 1), was 90 feet high. It was designed to handle the maximum throughput of the separator system, $30 \mathrm{MMSCFD}$. It was equipped with a pilot light, an automatic electric ignition system, and plumbing for injection of tritiated liquid hydrocarbons or water, if desired. In practice, the injection features were not used. No measurable liquid hydrocarbons were found. Separated water was injected into a disposal well under the provisions of a permit (l)' from the Water Quality Control Division, Colorado Department of Health.

\subsection{LIQUID STORAGE AND DISPOSA I SYSTEMS}

\subsubsection{Water Tanks}

Four 400-barrel tanks (Figure 3) we re used for temporary storage of produced tritiated water prior to disposal. The tanks were provided with high- and lowlevel sensors to actuate valves and controllers as appropriate. Level guages were included for documentation and disposal management purposes.

Heaters were included to permit use under freezing weather conditions. In practice, only tanks 2,3 , and 4 were used for the temporary storage of produced tritiated water. Tank 1 was used for the storage of fresh uncontaminated water which was used to dilute the produced water for two purposes. It was found necessary during the November 1973 testing to cool the produced water by dilution to avoid boiling in the tanks. The addition of the fin-fan coolers after the first drawdown period obviated the subsequent need for this. However, as will be shown later, it was found that the level of tritium concentration in the produced water exceeded the maximum of $50,000 \mathrm{pCi} / \mathrm{ml}$ specified in Reference 1. Accordingly, it was necessary during both drawdown periods to dilute the produced water so that the cumulative concentration of tritium remained below the permitted maximum.

\subsubsection{Condensate Storage}

Two 1,000-gallon, low-pressure storage vessels were provided to store any tritiated hydrocarbon condensate which might be separated in the three-phase, low-pressure separator. In practice, no measurable quantities of liquid hydrocarbons were found. Had there been any, it would have been sampled and analyzed for tritium and disposed of by dispersal and burning in the gas/air stream leaving the flare stack. 


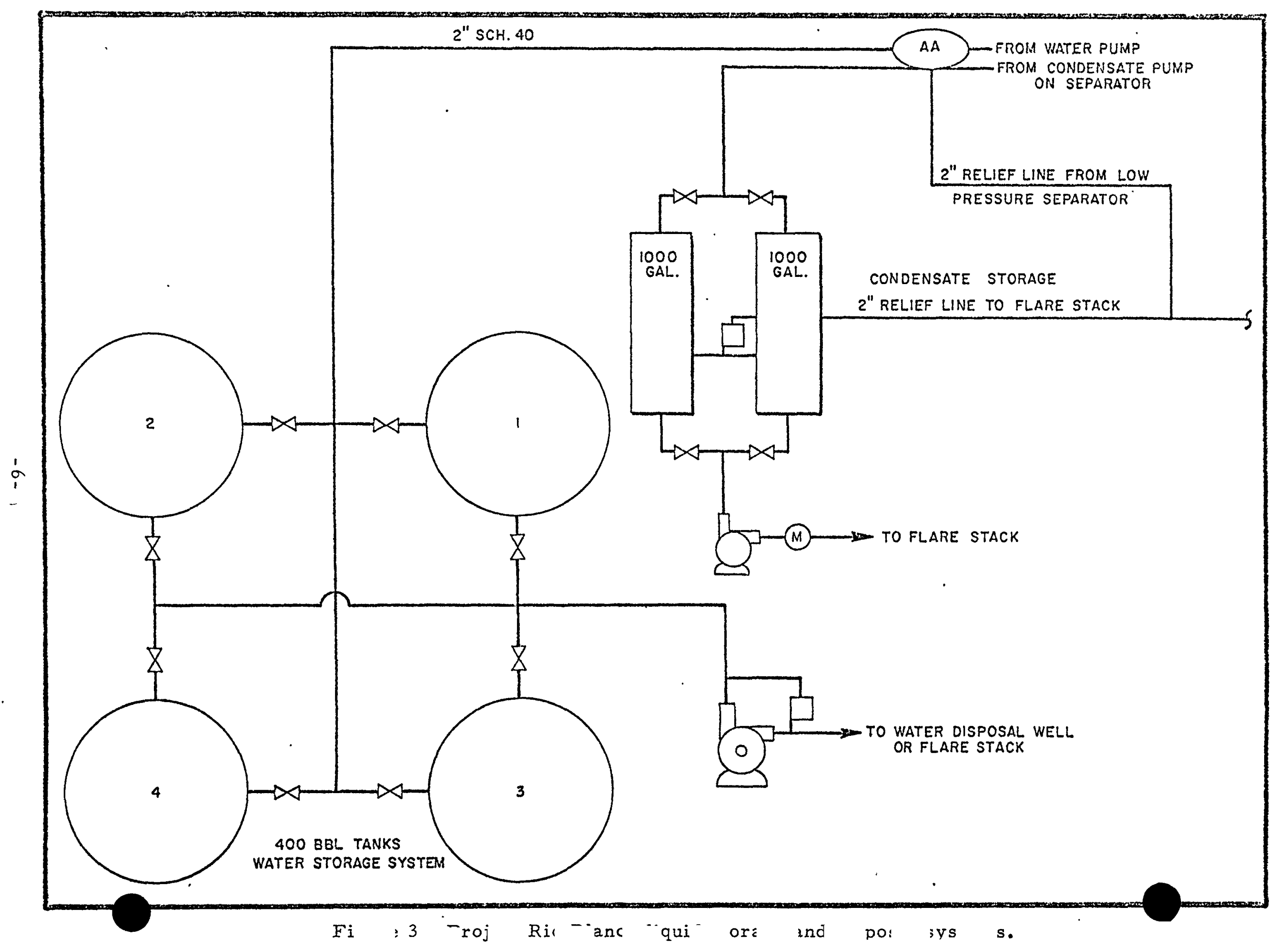




\section{2. $3 \quad$ Disposal Well}

A gas well, Fawn Creek Government Number 1, which was located about 1,300 feet from the emplacement well, had been selected as a disposal well for the produced tritiated water. The well was dually completed as a gas producer and as a subsurface disposal well. The detail of the as-built downhole completion of this well is shown in Figure 4.

The 5-1/2-inch casing is cemented in a 7-7/8-inch hole from total depth to 4,773 feet and in a 9-inch hole from 4,773 feet to 4,660 feet. Note that an interval of 474 feet separates the top of the water injection zone from the bottom of the gas producing zone. The interval between the two zones is predominantly shales and siltstones with some interbedded sands, as described in the well summary given in Reference 2.

After sampling of a filled storage tank and analysis for tritium, the water was metered and transferred to the injection zone by means of a $50-\mathrm{hp}$ triplex pump at flow rates of about 50 barrels per hour and with injection pressures at the wellhead never exceeding 1,580 psig. The 2 -inch lines from the tanks to the well were wrapped with heating tape and insulated to permit operation during freezing conditions. 


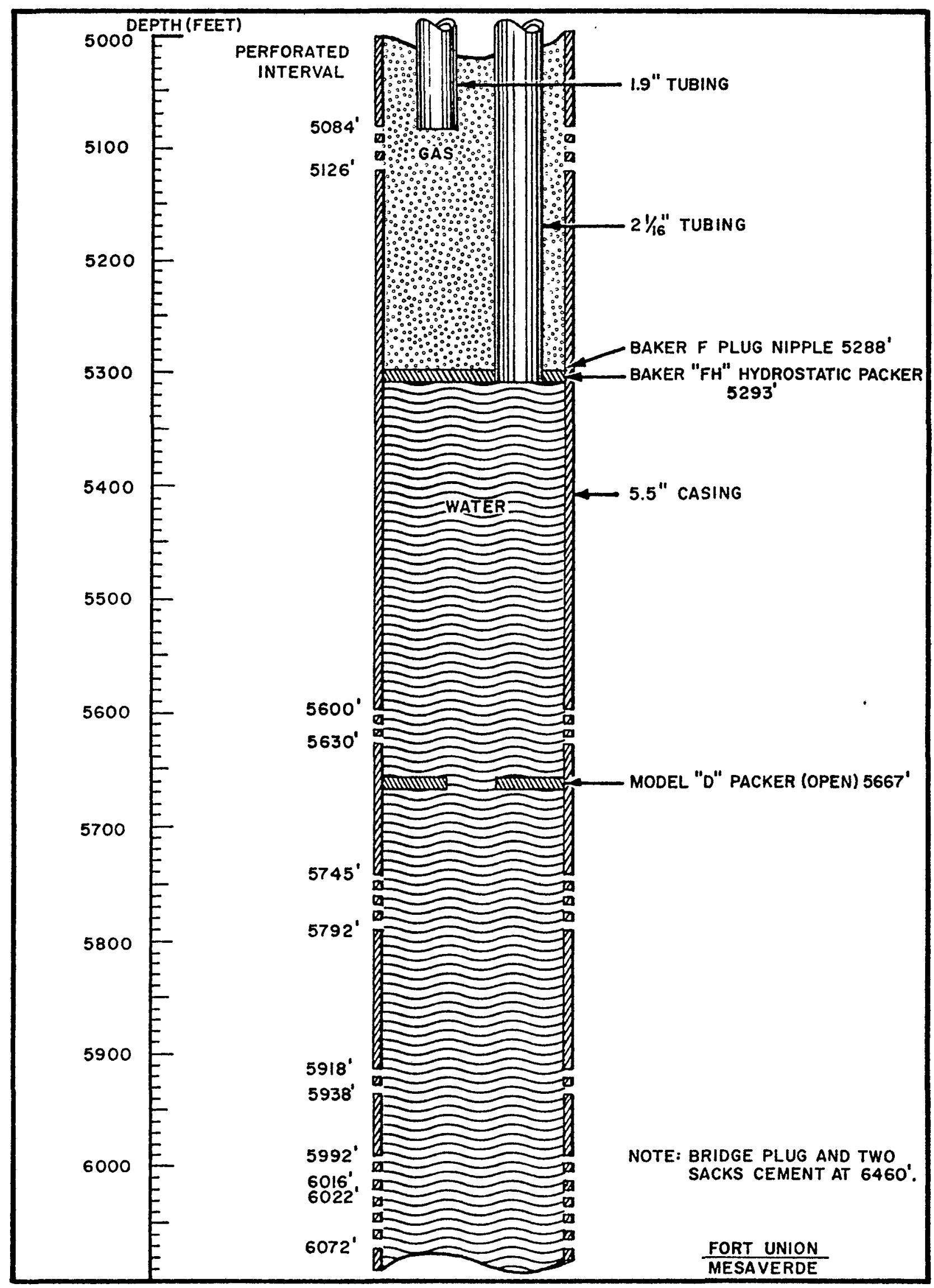

Figure 4.| As-built downhole completion detail, Fawn Creek Government No. 1 Well. 


\section{RADIOLOGICA L MONITORING SYSTEM}

Radiological protection and documentation of radioactive effluents were provided during the two chimney drawdown periods by the Eberline Instrument Corporation (EIC) under contract to CER Geonuclear Corporation. Most of the field equipment used for this purpose was furnished by the Government, having been procured by EIC under its prior contract with the Atomic Energy Commission's Nevada Operations Office. CER furnished its own TRY-KRY monitoring system for gaseous effluent documentation. In addition, $C E R$ procured from EIC the design, fabrication, and assembly of a gas conditioning skid to dry the sample gas prior to admitting it to other processing and counting equipment. In addition to the CER TRY-KRY monitoring system, the principal elements of the continuous radiological monitoring equipment are described below and are shown in Figure 5 as a schematic of the production test gas sampling system. The sample section shown in Figure 5 was between the separator and the meter run.

\section{$3.1 \quad$ TRY-KRY MONITORING SYSTEM}

The TRY-KRY system provides for introduction of the sample gas via appropriate regulators, flowmeters, etc., into a shielded proportional counter either in a static or flowing mode. The associated electronics provide for three channels of discrimination and teleprinter readout. The system,was normally operated in the flowing mode at 25 psia, the sample gas being diluted with fresh methane in the ratio of about 1 to 24 to provide a good counting gas. With the discriminator levels used and the dilutions required, the system had a 2 -sigma sensitivity for ${ }^{85} \mathrm{Kr}$ of about $0.5 \mathrm{pCi} / \mathrm{ml}$ in the presence of ${ }^{3} \mathrm{H}$ and ${ }^{37} \mathrm{Ar}$. In the presence of the other radionuclides, the system's 2-sigma sensitivity for ${ }^{37} \mathrm{Ar}$ was initially about $5 \mathrm{pCi} / \mathrm{ml}$, improving to $1 \mathrm{pCi} / \mathrm{ml}$ as the ${ }^{85} \mathrm{Kr}$ concentration dropped. The system's sensitivity for ${ }^{3} \mathrm{H}$ was not adequate to document this radionuclide adequately in the presence of ${ }^{37} \mathrm{Ar}$ and ${ }^{85} \mathrm{Kr}$. It is estimated that the 2 -sigma sensitivity for ${ }^{3} \mathrm{H}$ was about $25 \mathrm{pCi} / \mathrm{ml}$.

The system was calibrated by the use of separate standards, commercial grade methane containing known quantities of ${ }^{3} \mathrm{H}$ or ${ }^{85} \mathrm{Kr}$. It was further calibrated daily for gain by the use of the $5.9 \mathrm{kev}$ manganese $\mathrm{x}$-ray resulting from the decay of an $55 \mathrm{Fe}$ source. Several 1,000 -second counts were obtained and analyzed daily for ${ }^{37} \mathrm{Ar}$ and ${ }^{85} \mathrm{Kr}$. The ${ }^{85} \mathrm{Kr}$ values were compared with the EIC values to select an appropriate mean value for the day's release. The EIC values for ${ }^{3} \mathrm{H}$ obtained as described below were used to correct the TRYKRY ${ }^{37} \mathrm{Ar}$ values for ${ }^{3} \mathrm{H}$ counts in the ${ }^{37} \mathrm{Ar}$ window. Calibration of the system for ${ }^{37} \mathrm{Ar}$ was performed after the fact by correlation of observed count-rates with several corresponding gas sample analyses as reported by the Lawrence Livermore Laboratory (LLL). 


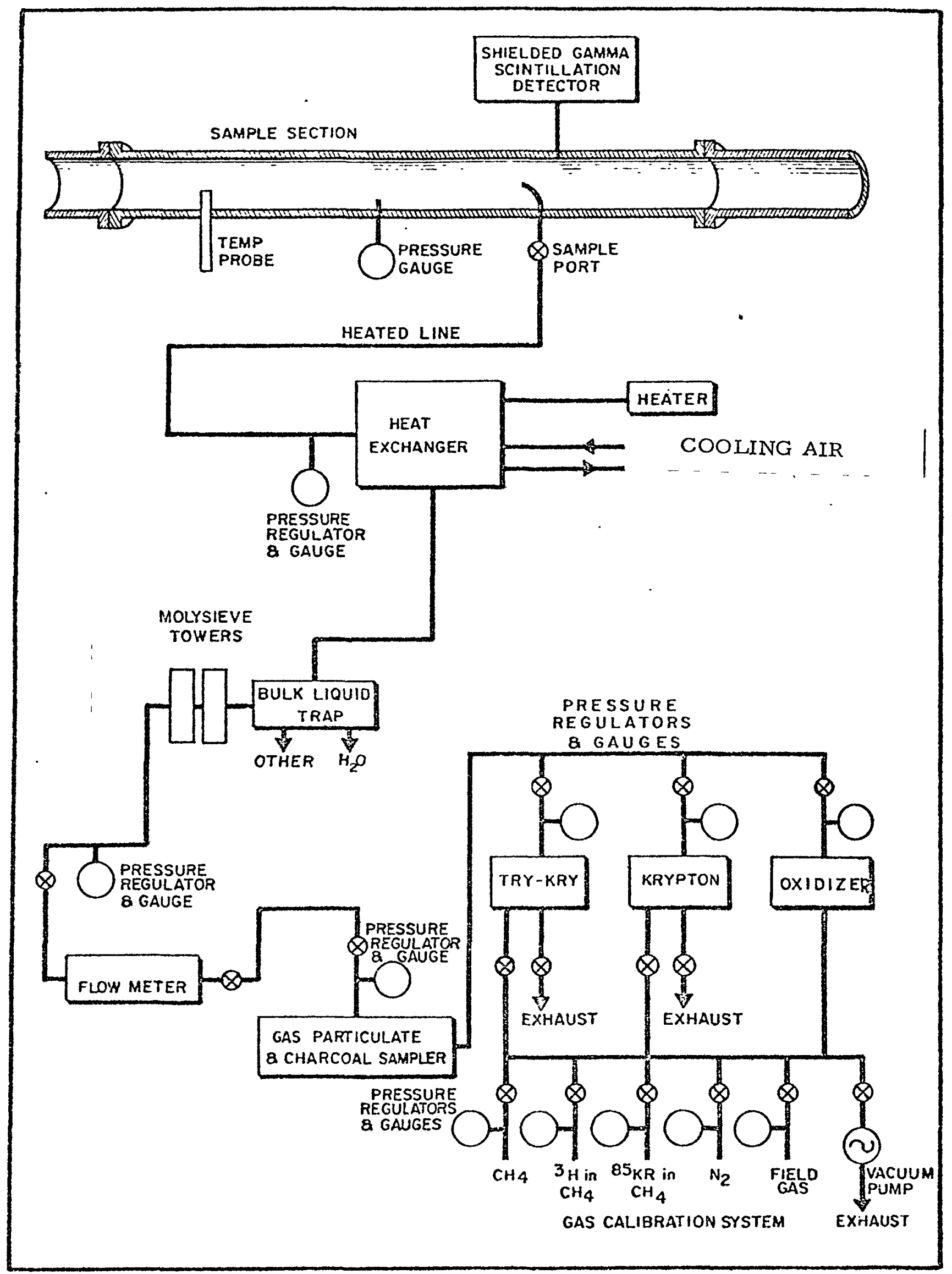

Figure 5. Production test gas sampling system. 
The EIC krypton chamber detector consists of a geiger-muller tube installed in a chamber shielded with 3 inches of lead. The readout of the detector is accomplished with an alarming rate meter ( $R M-3 C$ ). The response of the instrument is $50 \mathrm{CPM}$ per $\mathrm{pCi} / \mathrm{ml}$ of $85 \mathrm{Kr}$ in gas at $14.7 \mathrm{psia}$. The typical background count-rate at the site elevation is about 30 CPM. The sensitive volume (3.85 liters) of the detector is lined with stainless steel. The detection cutoff of the $30 \mathrm{mg} / \mathrm{cm}^{2}$ wall thickness is about $150-\mathrm{kev}$ beta energy. The unit operates continuously with a flow of sample gas from the gas conditioning skid and is recorded on a strip chart recorder. Calibration of the unit with chemical purity methane containing a known concentration of ${ }^{85} \mathrm{Kr}$ is performed weekly.

\section{$3.3 \quad$ OXIDIZER}

For preparation of gas samples for ${ }^{3} \mathrm{H}$ analysis, an oxidizer is used. Dry gas from the gas conditioning skid is burned with oxygen in a Packard TriCarb oxidizer, with supplementary controls and flowmeters. The water of combustion is recovered with a definable recovery efficiency and counted by liquid scintillation means with a sensitivity of about $2 \mathrm{pCi} / \mathrm{ml}$ of water. With the chemical composition of the chimney gas $\left(60 \% \mathrm{CO}_{2}, 30 \% \mathrm{CH}_{4}, 10 \% \mathrm{H}_{2}\right)$, this corresponds to a sensitivity of about $1 \mathrm{pCi}^{3} \mathrm{H} /$ liter of gas.

\section{4 LIQUID SCINTILIATION SYSTEM}

All water, urine, and hydrocarbon samples are assayed for ${ }^{3} \mathrm{H}$ in a Packard Tri-Carb Liquid Scintillation Spectrometer. Generally, an aliquot of $4 \mathrm{ml}$ is pipetted into a $22 \mathrm{-ml}$ liquid scintillation vial and $15 \mathrm{ml}$ of Aqua-Sol added. The vial is placed in the liquid scintillation system to dark adapt and cool and then counted for 10 minutes. Under these conditions, the expected sensitivity is $2 \mathrm{pCi} / \mathrm{ml}$ of liquid. In the case of urine samples, it is necessary to avoid quenching by diluting $1 \mathrm{ml}$ of urine with $3 \mathrm{ml}$ of distilled water. For these, the expected sensitivity is $10 \mathrm{pCi} / \mathrm{ml}$ for ${ }^{3} \mathrm{H}$. In the case of hydrocarbon samples, the effect of quenching is kept negligible by varying the size of the aliquot according to the clarity of the sample. The sensitivity may vary over the range of $2 \mathrm{pCi} / \mathrm{ml}$ to $80 \mathrm{pCi} / \mathrm{ml}$. Calibration of the system for efficiency of counting is effected by use of a National Bureau of Standards certified tritiated water standard.

\section{5 OTHER SAMPLE ANALYSIS EQUIPMENT}

Almost all the data hereafter reported were obtained with the equipment described in paragraphs 3.1 through 3.4 In addition, the counting trailer was equipped for measurement of gross alpha, gross beta, and gross gamma activities. In the case of air particulate filters, the expected sensitivities are 10, 100, and $200 \mathrm{pCi} / \mathrm{sample}$ for alpha, beta, and gamma, respectively, referenced to ${ }^{239} \mathrm{Pu},{ }^{90} \mathrm{Sr}$, and ${ }^{137} \mathrm{Cs}$. A NaI (T1) scintillation counter 
with multichannel analyzer was also available and used for gamma spectrometry with a resolution of $10 \mathrm{Kev}$ per channel. A GeLi scintillation counter with multichannel analyzer was available at an EIC laboratory. The latter has a resolution of $1 \mathrm{Kev}$ per channel. 


\section{EFFLUENT DOCUMENTATION}

\subsection{GAS AND WATER PRODUCTION}

The RB-E-01 well was produced first for an extended period (1-3/4 hours) through the drilling well control (DWC) unit on October 25, 1973 to verify good communication with the chimney. Smaller quantities of gas were produced previously on October 16 and 17 in unseccessful attempts to establish good communication. Gas pressure was also available for sampling in the annulus on October 13, 1973. Approximately 3 weeks later, after moving out the rig and associated equipment and completing the testing installation shown in Figures 2 and 3, the first production was initiated at $1245 \mathrm{MST}$, November 14, 1973. The test was continued until $1007 \mathrm{MST}$, November 20, 1973, with a shutdown from $2200 \mathrm{MST}$, November 14, 1973, to $1135 \mathrm{MST}$, November 16, 1973, to correct initial problems encountered. The test was performed without the fin-fan coolers shown in Figure 2. During this period the bottom-hole pressure and temperature conditions, as measured at a depth of 5, 160 feet below ground level (about 500 feet above the perforations in the production liner), changed from $2,004 \mathrm{psig}$ and $385^{\circ} \mathrm{F}$ to $1,218.5$ psig and $432^{\circ} \mathrm{F}$. The operating pressure of the separator was maintained in the range of 725 to 1,000 psig while the operating temperature rose within 12 hours to the neighborhood of $250 \mathrm{o} F$ and thereafter more slowly, reaching $300{ }^{\circ} \mathrm{F}$ within 36 hours and a peak of $345^{\circ} \mathrm{F}$ at shut-in. The initial specific gravity of the dry gas, as measured downstream of the EIC gas conditioning skid with a Ranarex instrument, was about 1.136 relative to air, decreasing slowly to 1.105 at the end of the first chimney drawdown.

The second production test, during which the fin-fan coolers shown in Figure 2 were operational, began at $1535 \mathrm{MDT}$, January 28, 1974, and continued until $0820 \mathrm{MDT}$, February 15, 1974. The bottom-hole flowing pressure and temperature conditions were initially about $1,630 \mathrm{psig}$ and $400{ }^{\circ} \mathrm{F}$. The pressure dropped steadily to a final value of $430 \mathrm{psig}$, while the temperature rose to a peak value of $452^{\circ} \mathrm{F}$ on February 3, 1974, and then dropped very slowly to a final value of $438^{\circ} \mathrm{F}$. The separator operating pressure was maintained in the neighborhood of 600 psig during the first part of the test and dropped stepwise to a final value of 170 psig during the latter part as the gas production rate was reduced. The operation of the fin-fan coolers kept the average operating temperature of the separator in the range of 100 to $150 \mathrm{o}$. In consequence, the fraction of wate $r$ vapor in the flared gas in the second drawdown was about 8 percent of what it had been in the first drawdown. The specific gravity of the dry gas was initially 0.975 , climbed to about 1.01 within 12 hours, dropped slowly to a low of 0.92 on February 9 and rose again to the range of 0.941 to 0.948 on the last day. A summary of the gas and water production data for both drawdown periods is presented in Table 1. 
Table 1. Gas and water production.

\begin{tabular}{|c|c|c|c|c|}
\hline $\begin{array}{l}\text { Date Ending } \\
\text { at } 0800\end{array}$ & \multicolumn{2}{|c|}{$\begin{array}{l}\text { Gas Flared } \\
\left(\text { MMSCF } F^{\mathrm{a}}\right)\end{array}$} & $\begin{array}{c}\text { Water } \\
\text { Vapor } \\
\text { Flared (lbs) }\end{array}$ & $\begin{array}{c}\text { Liquid Water } \\
\text { Separated } \\
\text { (BBI) }\end{array}$ \\
\hline \multicolumn{5}{|l|}{1973} \\
\hline Oct 17 & 0.14 & 0.14 & $\mathrm{~b}$ & $b$ \\
\hline Oct 18 & 0.10 & 0.10 & $\mathrm{~b}$ & $\mathbf{b}$ \\
\hline Oct 26 & 0.40 & 0.40 & $\mathrm{~b}$ & 47 \\
\hline Nov 15 & 4.54 & 4.63 & 4,269 & 136 \\
\hline Nov 17 & 8.22 & 8.51 & 13,756 & 398 \\
\hline Nov 18 & 8.12 & 8.68 & 26,563 & 443 \\
\hline Nov 19 & 7.47 & 8.24 & 36,524 & 409 \\
\hline Nov 20 & 7.25 & 8.33 & 51,228 & 412 \\
\hline Nov 21 & 0.59 & 0.70 & 5,218 & 28 \\
\hline Ist Drawdown & 36.83 & 39.73 & 137,558 & 1,873 \\
\hline \multicolumn{5}{|l|}{1974} \\
\hline $\operatorname{Jan} 29$ & 4.17 & 4.18 & 661 & 223 \\
\hline $\operatorname{Jan} 30$ & 6.09 & 6.14 & 2,062 & 433 \\
\hline $\operatorname{Jan} 31$ & 6.21 & 6.25 & 1,459 & 536 \\
\hline Feb 1 & 6.13 & 6.17 & 1,625 & 636 \\
\hline Feb 2 & 3.48 & 3.49 & 557 & 377 \\
\hline Feb 3 & 4.34 & 4.36 & 894 & 544 \\
\hline Feb 4 & 4.36 & 4.38 & 750 & 631 \\
\hline Feb 5 & 4.01 & 4.02 & 622 & 661 \\
\hline Feb 6 & 3.80 & 3.81 & 608 & 738 \\
\hline Feb 7 & 3.22 & 3.24 & 940 & 721 \\
\hline Feb 8 & 2.79 & 2.81 & 853 & 705 \\
\hline Feb 9 & 2.22 & 2.23 & 392 & 586 \\
\hline Feb 10 & 2.14 & 2.16 & 636 & 653 \\
\hline Feb 11 & 2.25 & 2.27 & 701 & 780 \\
\hline Feb 12 & 2.06 & 2.08 & 1,038 & 810 \\
\hline Feb 13 & 1.82 & 1.84 & 935 & 807 \\
\hline Feb 14 & 1.62 & 1.64 & 931 & 807 \\
\hline Feb 15 & 1.49 & 1.51 & 850 & 822 \\
\hline 2nd Drawdown & 62.20 & 62.58 & 16,514 & 11,470 \\
\hline Total & 99.03 & 102.31 & 154,072 & 13,343 \\
\hline
\end{tabular}

a At 14.7 psia, $60^{\circ} \mathrm{F}$.

b Negligible. 
For the purposes of this report on radioactivity release documentation, small adjustments have been made to the volumetric data reported elsewhere to compensate for the increasing fraction of water vapor in the flared wet gas during the period November 14 to 20, 1974. Shown in Table 2 and described below is a reconcilement of the production data developed in the field and the data reported in Table 1 for the first drawdown.

The values for produced wet gas shown to the left of Table 2 were calculated, in part, by the use of specific gravity values measured for the dry gas and of corresponding values for compressibility. The fraction of water vapor in the gas leaving the separator was taken as the ratio of the partial pressure of steam at the temperature of the separator to the total pressure at the separator. These procedures were generally suitable throughout the two drawdowns, but they did not take into account the effect of the water vapor (when the fraction was significant as during much of the first drawdown) on the specific gravity and compressibility of the wet gas at the orifice plate, nor did it take into account the effect of the total pressure on the partial pressure of steam.

To make the appropriate correction, the mole fraction of water vapor was calculated for each hourly observation of separator conditions. Use was made of the Poynting equation (3) which, when integrated between the limits of the vapor pressure of the liquid and the total pressure, is as follows:

$$
f=\frac{P_{v}}{P_{t}} \exp \frac{V_{l}\left(P_{t}-P_{v}\right)}{R(T+460)}
$$

where $\quad f=$ mole fraction of vapor

$P_{\mathrm{V}}=$ vapor pressure of liquid, psia

$\mathrm{P}_{\mathrm{t}}=$ total pressure of gas and vapor, psia

$\mathrm{V}_{1}=$ specific volume of liquid, $\mathrm{ft}^{3} / \mathrm{lb}$

$\mathrm{T}=$ degrees Fahrenheit

$R=0.5961$ psia $\mathrm{ft}^{3} / 1 \mathrm{~b}-{ }^{\circ} \mathrm{R}$

To illustrate, for $P_{t}=1,000$ psia and $T=300{ }^{\circ} \mathrm{F}$, the value of the exponential function is 1.037 , so the typical correction is less than 4 percent.

The calculated mole fractions were averaged over each 24-hour period on a basis weighted by the flow-rate and are shown in the third column of Table 2. Noting that the solubility of $\mathrm{CO}_{2}$ in liquid water is less than 0.01 mole fraction at the prevailing separator operating conditions, the effect of $\mathrm{CO}_{2}$ in solution on the evaporation of water is assumed to be negligible.

The mole fraction data were then used to calculate the specific gravity of the wet gas from the observed specific gravity of the dry gas. They were further used to calculate the chemical composition of the wet gas with the approximation that the dry gas was $60 \% \mathrm{CO}_{2}, 30 \% \mathrm{CH}_{4}$, and $10 \% \mathrm{H}_{2}$. Given the 
Table 2. Refinement of gas production data.

\begin{tabular}{|c|c|c|c|c|c|c|}
\hline $\begin{array}{c}1974 \text { Date } \\
\text { Ending } 0800 \\
\end{array}$ & $\begin{array}{r}\text { Produced } \\
\text { Wet Gas } \\
\text { (MMSCF) }\end{array}$ & $\begin{array}{c}\text { Mean } \\
\text { Mole Fraction } \\
\text { Water Vapor } \\
\end{array}$ & $\begin{array}{l}\text { Wet Gas } \\
\text { Correction } \\
\text { Eactor }\end{array}$ & $\begin{array}{l}\text { Refined } \\
\text { Wet Gas } \\
\text { (MMSCF) }\end{array}$ & $\begin{array}{c}\text { Flared } \\
\mathrm{H}_{2} \mathrm{O} \text { Vapor } \\
\text { (MMSCE) }\end{array}$ & $\begin{array}{c}\text { Produced } \\
\text { Dry Gas } \\
\text { (MMSCF) }\end{array}$ \\
\hline Oct 17 & 0.14 & a & 1.0 & 0.14 & $a$ & 0.14 \\
\hline Oct 18 & 0.10 & a & 1.0 & 0.10 & a & 0.10 \\
\hline Oct 26 & 0.40 & $a$ & 1.0 & 0.40 & a & 0.40 \\
\hline Nov 18 & 8.52 & 0.0643 & 1.019 & 8.68 & 0.56 & 8.12 \\
\hline Nov 19 & 8.02 & 0.0936 & 1.028 & 8.24 & 0.77 & 7.47 \\
\hline Nov 20 & 8.03 & 0.1295 & 1.037 & 8.33 & 1.08 & 7.25 \\
\hline Nov 21 & 0.67 & 0.1530 & 1.044 & 0.70 & 0.11 & 0.59 \\
\hline Total & 38.90 & & & 39.73 & 2.90 & 36.83 \\
\hline
\end{tabular}

a Negligible. 
chemical composition of the wet and dry gas for each day of testing, the compressibilities were determined by the calculation of pseudocritical temperatures and pressures for the mixtures and the use of reduced coordinates (4).

The wet gas correction factor shown in the fourth column of Table 2, then, is simply the square root(5) of the ratio for dry and wet gas of the gravitycompressibility product. The remainder of Table 2 is self-explanatory.

\subsection{RADIOACTIVITY CONCENTRATIONS - CER/EIC MEASUREMENTS}

Table 3 presents results of field measurements made by CER and EIC of the concentrations of radionuclides in both the gas and liquid products, the latter consisting entirely of water. At no time were any measurable hydrocarbon condensates encountered. The tabulated data cover the principal radionuclides in the produced gas $\left({ }^{3} \mathrm{H},{ }^{85} \mathrm{Kr}\right.$, and $\left.37 \mathrm{Ar}\right)$ and the only radionuclide $\left({ }^{3} \mathrm{H}\right)$ observed in the produced water. The concentrations of ${ }^{85} \mathrm{Kr}$ and ${ }^{3} \mathrm{H}$ are plotted in Figure 6 together with quadratic-least-square-fits to the data for each of the two drawdown periods.

\section{3 \\ RADIOACTIVITY CONCENTRATIONS - LLL LABORATORY MEASUREMENTS}

The results of laboratory measurements of gas samples collected during reentry drilling and the two drawdowns by EIC for the Lawrence Livermore Laboratory are presented in Table 4. The radionuclides documented are

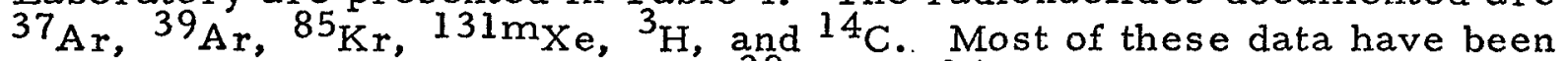
extracted from Reference 6 . The ${ }^{39} \mathrm{Ar}$ and ${ }^{14} \mathrm{C}$ in $\mathrm{CH}_{4}$ data have subsequently been acquired by private communication $(7)$.

The values shown for cumulative dry gas production have been derived from Table 1 and the daily testing logs by interpolation to the proper sampling time. The data for ${ }^{85} \mathrm{Kr}$ and ${ }^{3} \mathrm{H}$ are illustrated in Figure 7 , together with quadratic least square fits to the data.

\section{4 DISPOSITION OF RADIOACTIVITY}

The disposition of the principal radionuclides is indicated in Table 5 . In summary, slightly over $52 \mathrm{Ci}$ of ${ }^{3} \mathrm{H}$ and approximately $775 \mathrm{Ci}$ of $85 \mathrm{Kr}$ were released through the stack to the atmosphere, while about $150 \mathrm{Ci}$ of ${ }^{3} \mathrm{H}$ in the form of tritiated water was injected into the Fawn Creek Government No. 1 well under the provisions of Reference 1. The difference between the $3_{\mathrm{H}}$ values for water separated and injected are attributable to sampling and meter errors.

Other minor releases of radioactivity have been estimated for ${ }^{131 \mathrm{~m} X e,}{ }^{39} \mathrm{Ar}$, ${ }^{14} \mathrm{C}$, and ${ }^{203} \mathrm{Hg}$ and are shown in Table 6. No measurable quantities of any 
Table 3. Field measurements of radionuclide concentrations.

\begin{tabular}{|c|c|c|c|c|c|}
\hline \multirow{2}{*}{$\begin{array}{l}\text { Date Ending } \\
\text { At } 0800 \\
\end{array}$} & \multicolumn{3}{|c|}{$\mathrm{pCi} / \mathrm{ml}$ of Dry Gas ${ }^{\mathrm{a}}$} & \multicolumn{2}{|c|}{$\mathrm{pCi}{ }^{3} \mathrm{H} / \mathrm{ml}$ (lig) } \\
\hline & $3_{\mathrm{H}}$ & $85 \mathrm{Kr}$ & $37 \mathrm{Ar}$ & Sep. b & Tanks c \\
\hline \multicolumn{6}{|l|}{1973} \\
\hline Oct 17 & 37.0 & 370 & 120 & -- & --- \\
\hline Oct 18 & 26.3 & 440 & 140 & $-\cdots$ & $-\infty$ \\
\hline Oct 26 & 30.0 & 470 & 127 & 4.5 & 4.5 \\
\hline Nov 15 & 29.5 & 405 & 93 & 33 & 14 \\
\hline Nov 17 & 27.9 & 440 & 81 & 45 & 30 \\
\hline Nov 18 & 23.1 & 430 & 77 & 56 & 59 \\
\hline Nov 19 & 23.9 & 440 & 71 & 56 & 62 \\
\hline Nov 20 & 25.1 & 390 & 66 & 66 & 65 \\
\hline Nov 21 & 25.3 & 370 & 61 & 62 & 57 \\
\hline \multicolumn{6}{|l|}{1974} \\
\hline $\operatorname{Jan} 29$ & 18.9 & 275 & $11.5 \mathrm{~d}$ & 44 & 56 \\
\hline $\operatorname{Jan} 30$ & 22.0 & 285 & 11.5 & 72 & 66 \\
\hline $\operatorname{Jan} 31$ & 19.1 & 275 & 10.9 & 71 & 71 \\
\hline Feb 1 & 15.8 & 265 & 7.7 & 81 & 81 \\
\hline Feb 2 & 15.6 & 255 & 6.6 & 85 & 66 \\
\hline Feb 3 & 15.1 & 240 & 10.1 & 78 & 68 \\
\hline Feb 4 & 14.0 & 220 & 10.0 & 82 & 73 \\
\hline Feb 5 & 12.3 & 215 & 9.7 & 70 & 77 \\
\hline Feb 6 & 12.7 & 205 & 7.8 & 82 & 79 \\
\hline Feb 7 & 10.1 & 185 & 6.3 & 78 & 75 \\
\hline Feb 8 & 9.5 & 165 & 5.3 & 77 & 74 \\
\hline Feb 9 & 8.8 & 150 & 5.2 & 76 & 78 \\
\hline Feb 10 & 7.3 & 150 & 2.4 & 78 & 77 \\
\hline Feb 11 & 6.3 & 135 & 3.2 & 78 & 78 \\
\hline Feb 12 & 5.2 & 110 & 4.1 & 76 & 77 \\
\hline Feb 13 & 4.5 & 95 & $3.4 d$ & 77 & 76 \\
\hline Feb 14 & 3.9 & 85 & $3.0 \mathrm{~d}$ & 78 & 77 \\
\hline Feb 15 & 3.4 & 75 & $2.6 \mathrm{~d}$ & 78 & 75 \\
\hline
\end{tabular}

\footnotetext{
a At 14. 7 Psia, $32^{\circ} \mathrm{F}$

b As measured in daily separator water samples

c As calculated from measurements of storage tank batch samples

d Estimated
} 


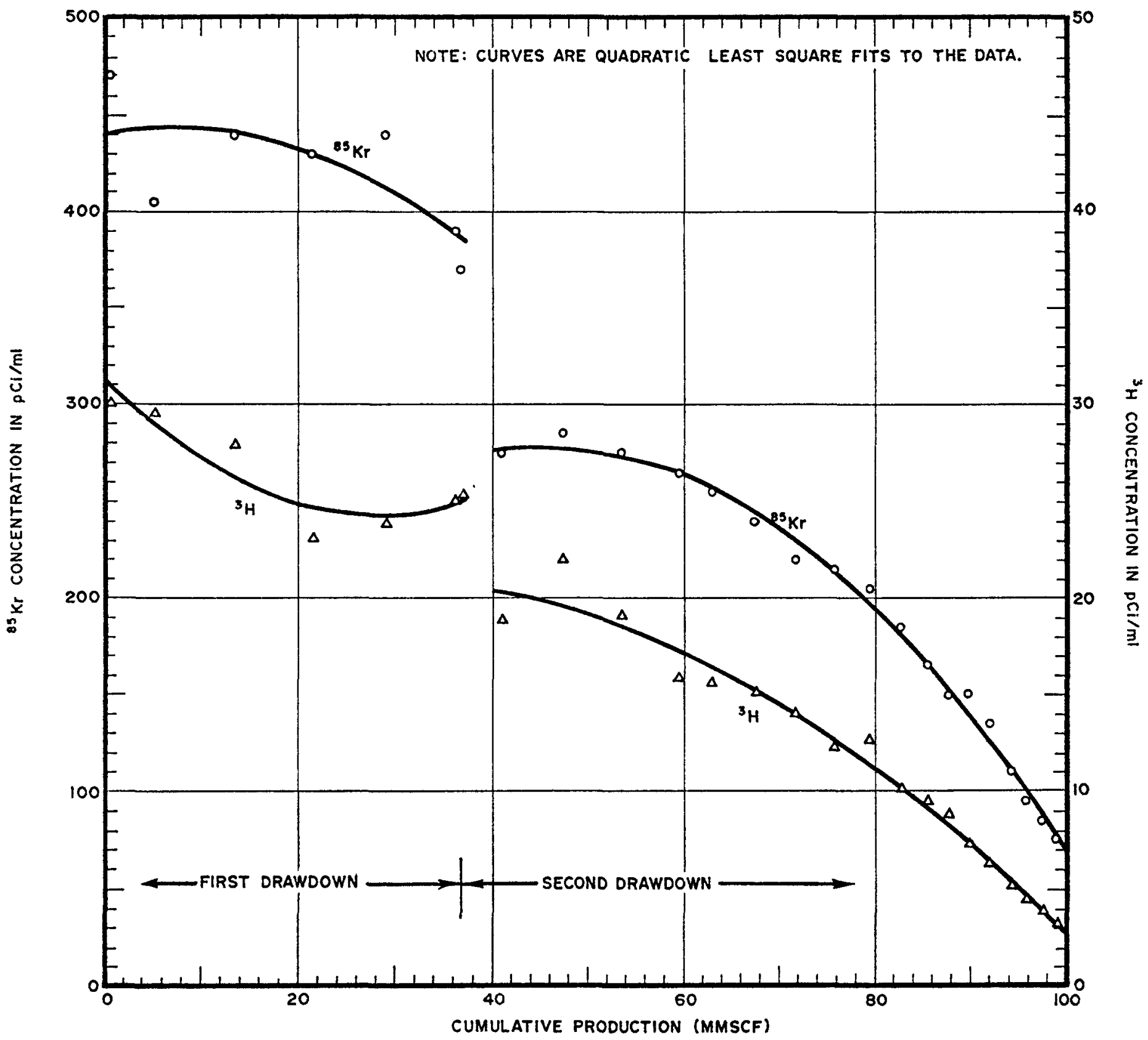

Figure 6. Gas sample data from CER/EIC field measurements. 
Table 4. LLL gas sample analyses.

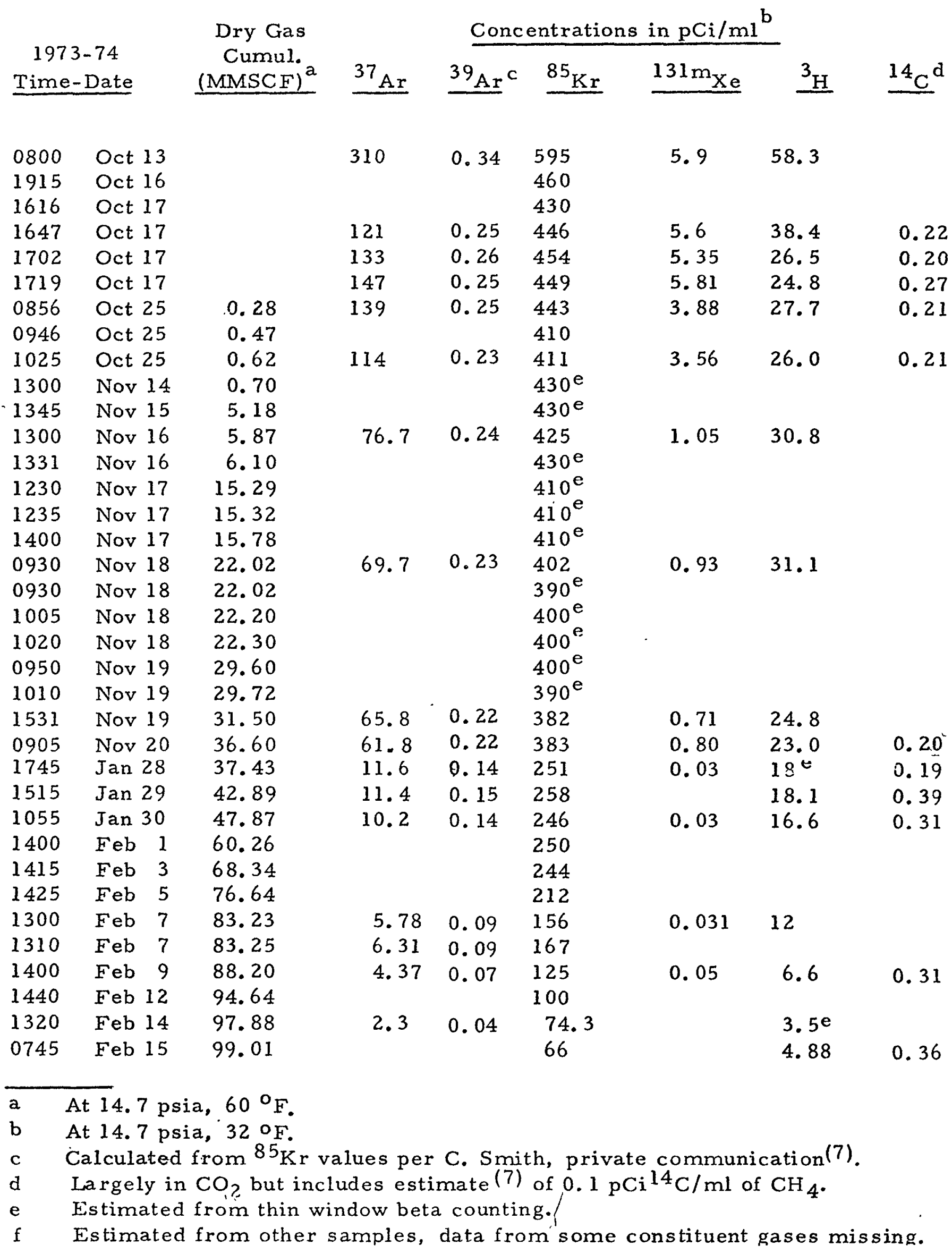




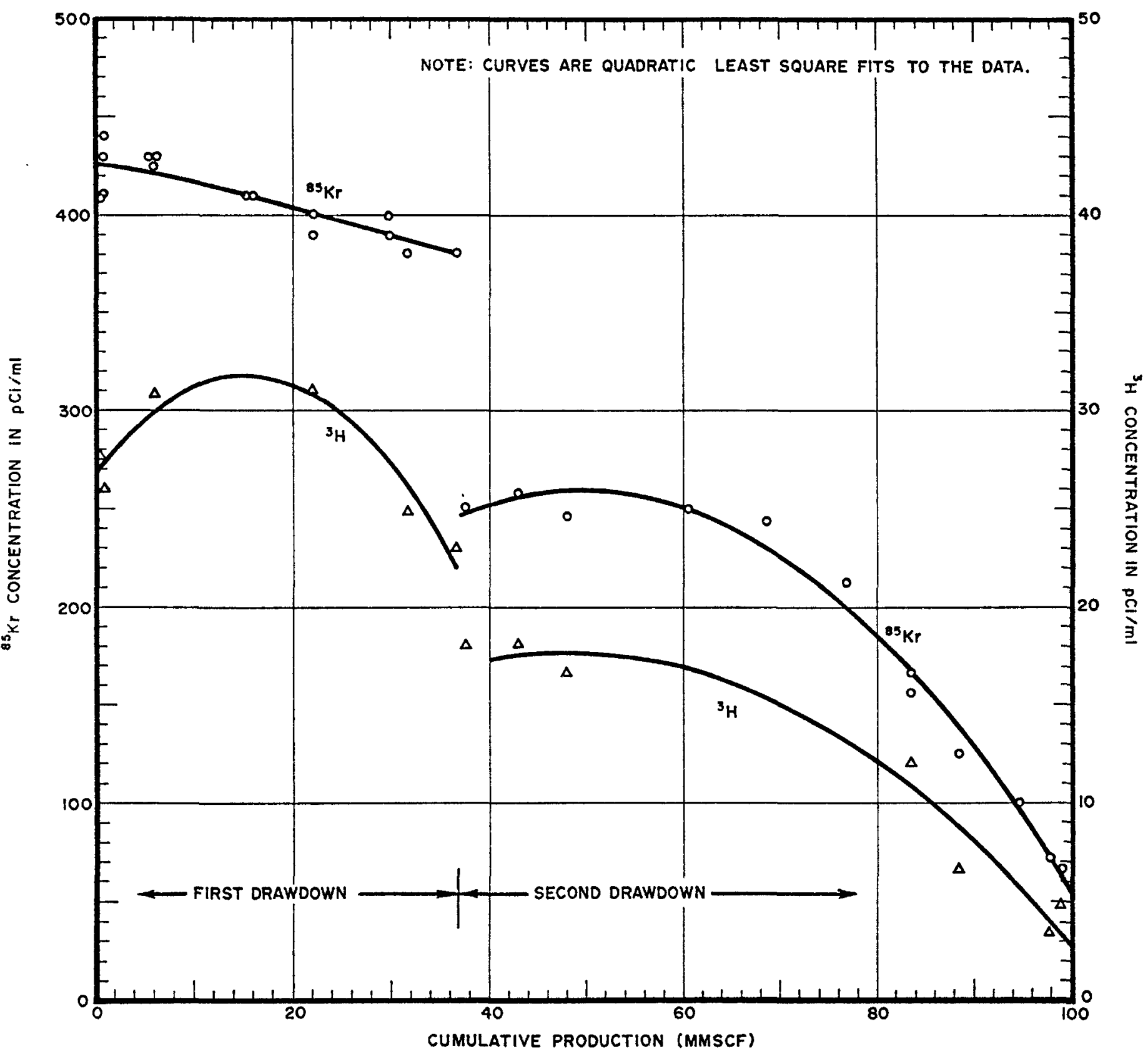

Figure 7. Gas sample data from LLL laboratory measurements. 
Table 5. Disposition of principal radionuclides.

Date Ending

At 0800

1973

Oct 17

Oct 18

Oct 26

Nov 15

Nov 17

Nov 18

Nov 19

Nov 20

Nov 21

lst Drawdown $25.30 \quad 3.60$

1974

$\operatorname{Jan} 29$

$\operatorname{Jan} 30$

Jan 31

Feb 1

$\mathrm{Feb} 2$

Feb 3

Feb 4

Feb 5

Feb 6

Feb 7

Feb 8

Feb 9

Feb 10

Feb 11

Feb 12

Feb 13

Feb 14

Feb 15

2nd Drawdown

Total

0.14

0.07

0.32

3.53

6.17

5.01

4. 80

4. 86

0.40

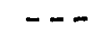

-..

0.03

0.19

0.71

1. 03

1. 51

0.13

0.57

$47.95 \quad 4.17$
1.390 .45

1. 18

5. 04

49.28

96.93

93.57

75.78

5.85

0.38

1. 36

11.32

17.84

16.76

14. 21

12. 82

0.96

15. 78

14. 93

15.54

\subsection{3}

0.71

2. 85

3. 94

3. 64

4. 32

0.28
Curies ${ }^{3} \mathrm{H}$ in $\mathrm{H}_{2} \mathrm{O}$

Separated Injecteda

$\begin{array}{ll}2.11 & 0.013 \\ 3.59 & 0.067 \\ 3.18 & 0.047 \\ 2.59 & 0.060 \\ 1.45 & 0.021 \\ 1.76 & 0.032 \\ 1.64 & 0.028 \\ 1.32 & 0.020 \\ 1.29 & 0.023 \\ 0.87 & 0.033 \\ 0.71 & 0.030 \\ 0.52 & 0.014 \\ 0.42 & 0.023 \\ 0.38 & 0.025 \\ 0.29 & 0.036 \\ 0.22 & 0.033 \\ 0.17 & 0.033 \\ 0.14 & 0.030\end{array}$

$417.11 \quad 76.10$

88.09
1. 28

1. 88

1. 81

1. 26

0.62

1.17

1. 17

1. 04

0.79

0.54

0.40

0.31

0.14

0.19

0.23

0.17

0.13

0.10

1. 56

4. 96

6. 05

8. 19

5.09

6.75

8. 23

7. 36

9.62

8.94

8.63

7. 08

8.10

9.67

9.79

9. 88

10.01

10. 19

2.99
359.16

13. 24

140.10
776.27

1. 99

4. 54

6.05

8. 19

3. 96

5. 88

7. 32

8. 09

9.27

8.60

8. 29

7.27

7. 99

9.67

9. 91

9. 75

9. 88

9. 80

136.45

134.40

$$
89.34 \quad 155.88 \quad 151.38 \quad 149.94
$$

\footnotetext{
a Injected into water disposal well.

b From separator sample data.

c From tank batch sample data.

d Includes injections in roll-up operation.
} 
radionuclides other than those shown in Tables 5 and 6 we re found, except for ${ }^{222} \mathrm{Rn}$, which occurs naturally in natural gas.

Table 6. Estimated minor releases.

Radionuclide

$13 \operatorname{lm} \mathrm{Xe}$

October 1973

November 1973

January-February 1974

${ }^{39} \mathrm{Ar}$

${ }^{14} \mathrm{C}$

Both drawdowns

${ }^{203} \mathrm{Hg}$

Both drawdowns

October-November 1973

January-February 1974

Estimated

Release in Curies
0.076
0.158
$\frac{0.072}{0.306}$
$1 \%$ of ${ }^{85}=$
$0.23 \%$ of ${ }^{85} \mathrm{Kr}=$
$0.02 \%$ of ${ }^{85} \mathrm{Kr}=$

0.44

$0.0565 \%$ of ${ }^{85} \mathrm{Kr}=$

0.76

not obseryed

$6.5 \times 10^{-6}$

\section{5 \\ COMPARISON OF CER/EIC WITH LLL MEASUREMENTS}

The field measurements of CER/EIC and the laboratory measurements of gas samples have been compared with respect to the ${ }^{85} \mathrm{Kr}$ and ${ }^{3} \mathrm{H}$ dry gas results. The comparison is presented in Table 7. In summary, the data appear to agree within normal ranges of error.

Table 7. Comparison of CER/EIC with LLL data.

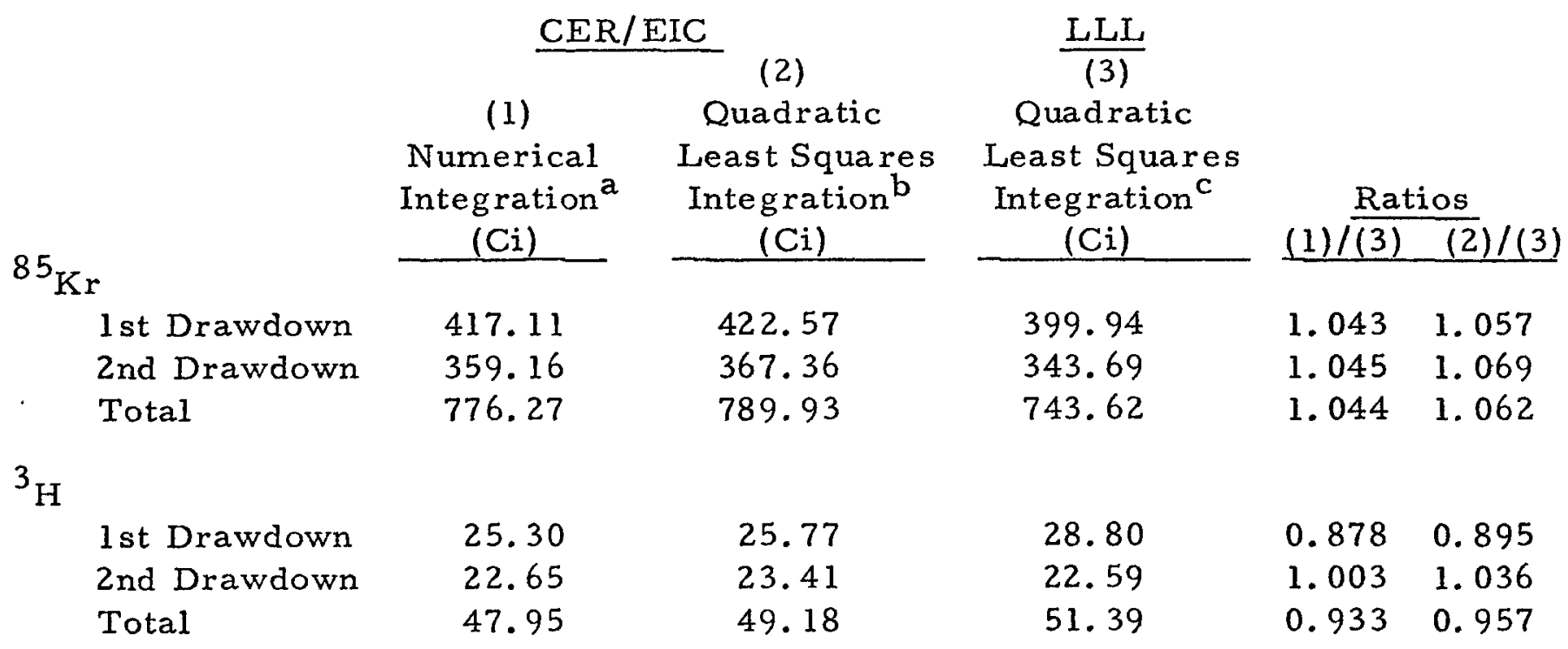

a Integrated numerically in Table 5.

b Values of integrals of quadratic least square fits to data, Figure 6 .

c Values of integrals of quadratic least square fits to data, Figure 7. 
$-24-$ 


\section{RADIOACTIVITY IN THE ENVIRONMENT}

The routine environmental sampling program ${ }^{(8)}$ for Project Rio Blanco was augmented in conjunction with the production testing of the well and consequent release of radioactive effluents.

\subsection{FIRST PRODUCTION TESTING}

During this period, the principal augmented environmental sampling effort was directed towards water, air particulate, and air moisture sampling. Some additional effort was expended in sampling soils, vegetation, and milkcow feed, in bioassays, and in external background measurements.

\subsubsection{Air Sampling}

Air samplers were operated at five locations (Figure 8): near the emplacement well, at the Equity camp and at the Berthelson, Brennan, and Norell ranches. The samplers were operated continuously from November 2 through November 20, 1974. These samplers pumped 8 to $10 \mathrm{CFM}$ in series through a 9-cm-diameter Whatman No. 41 filter paper and a charcoal cartridge. The particulate filters were changed every 2 days and were assayed separately for gross beta activity. The filters from the four off-site locations were composited for pulse-height analysis of the gamma spectrum, using the NaI crystal spectrometer system. The charcoal filters were changed at weekly intervals (approximately) and were assayed by gamma scan.

All filters were assayed for both beta and gamma activity within a day or two of the end of the collection period. In consequence, the sensitivity for both beta and gamma detection was about $1 \mathrm{pCi} / \mathrm{m}^{3}$ above natural background. No radionuclides other than those naturally occurring were detected. All samples assayed for both beta and gamma showed levels less than or equal to $1 \mathrm{pCi} / \mathrm{m}^{3}$.

\subsubsection{Air Moisture and Precipitation Sampling}

Air moisture samplers (molysieve in a long mesh basket) were exposed at four locations (Figure 8): the Equity camp, the Brennan ranch, a ranch house 3.5 miles down Fawn $\mathrm{Creek}$, and a hunting cabin 1.5 miles up Fawn Creek. The latter location was not inhabited at the time of the flaring. The sample collectors were changed daily from November 2 through November 19, 1974. Samples of snow were collected during the flaring at all four locations in a heavy snowstorm on November 19, 1973.

Liquids collected in air moisture and precipitation sampling were analyzed for tritium by liquid scintillation means with a detection sensitivity of $2 \mathrm{pCi} / \mathrm{ml}$. 


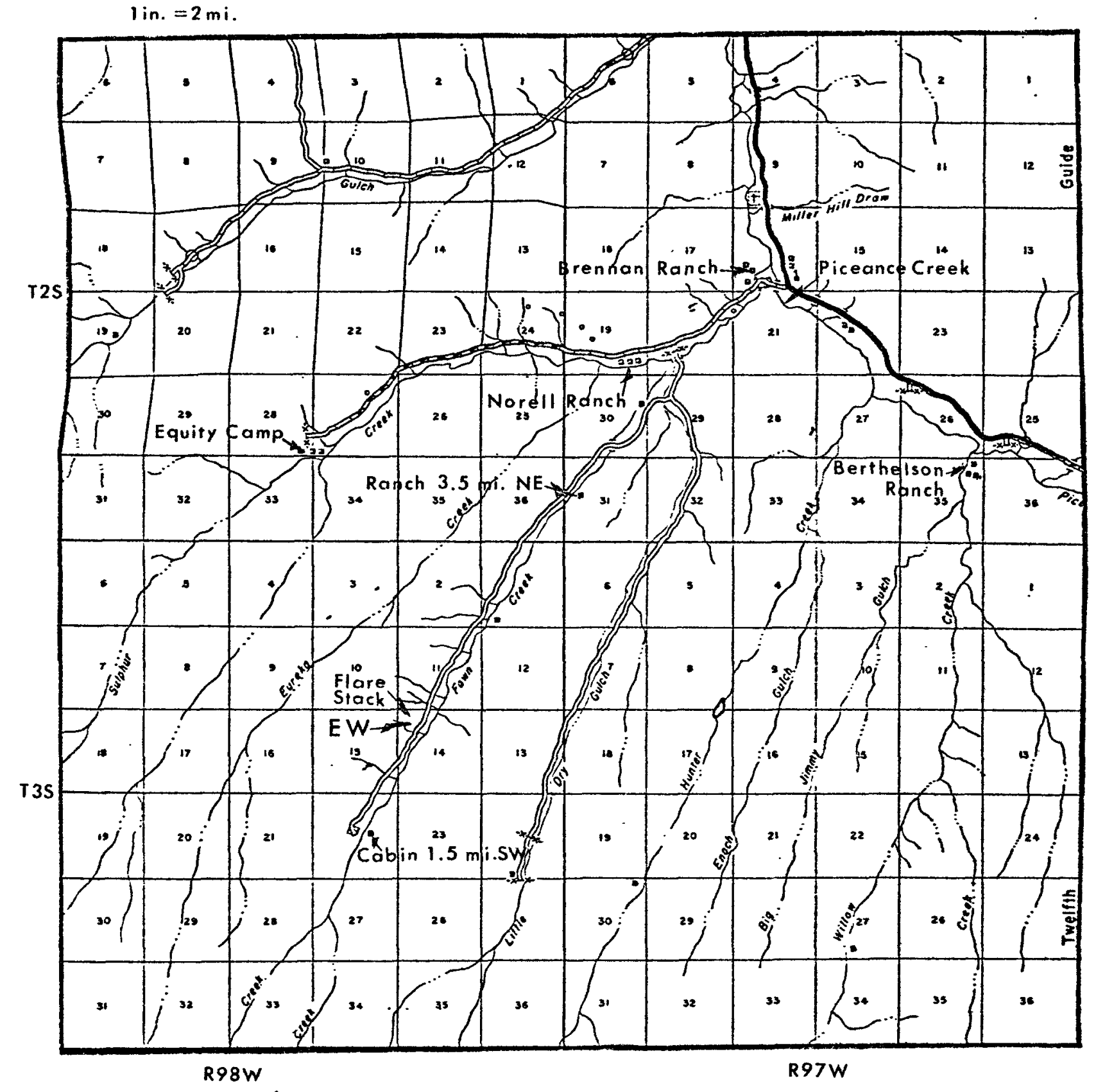

Figure 8. Close-in environmental monitoring points - production testing. 
No tritium was detected at or above this threshold in any air moisture or precipitation sample collected away from the project site.

\subsubsection{Site Air Moisture and Precipitation Sampling}

Air moisture and precipitation samples were also collected near the EW and the flarestack during the reentry drilling and first production test. They were processed in the same manner as described in paragraph 5.1.2. The results, some of which showed tritium levels somewhat above background, are given in Table 8 . The mean of the air moisture values during the period November 15 to 20,1973 , is about $4.5 \mathrm{pCi}{ }^{3} \mathrm{H} / \mathrm{ml}$ of liquid. Considering only the water of combustion leaving the flare stack in burning a mixture of $60 \% \mathrm{CO}_{2}, 10 \% \mathrm{H}_{2}$ and $30 \% \mathrm{CH}_{4}$, about $5.5 \times 10^{8} \mathrm{ml}$ (liq) of water were released during the first production testing, with an ${ }^{3} \mathrm{H}$ content of $25.3 \mathrm{Ci}$. An additional $6.2 \times 10^{7} \mathrm{ml}$ (liq) were flared as water vapor with an ${ }^{3} \mathrm{H}$ content of $3.6 \mathrm{Ci}$. The average concentration of ${ }^{3} \mathrm{H}$ in the released water was, then, about $47,000 \mathrm{pCi} / \mathrm{ml}$ (liq). The observed dilution factor was in excess of 10,000 .

\subsubsection{Water Sampling}

Water samples were collected at six close-in locations (Figure 8): the Equity camp, the Berthelson, Brennan, and Norell ranches, and from Fawn Creek 1.5 miles upstream and 1 mile downstream. Samples were collected at all locations on November 2, 1973, and at 3-day intervals starting on November 7, 1973. The final set of samples was taken on November 22, 1973.

Water samples were collected at 11 distant locations (Figure 9): Piceance Creek; the White River up- and downstream of the mouth of Piceance Creek; East Rifle Creek; Main Elk Creek; the Colorado River downstream of Roan Creek; and the municipal water supplies of Grand Junction, Grand Valley, Meeker, Rangely, and Rifle. Samples were collected at all locations at weekly intervals (approximately) starting on November 1, 2, 1973. The final set was taken on November 20, 22, 1973.

All samples were assayed for tritium by liquid scintillation means and for other radionuclides by gamma spectrometry. The sensitivity for detection of tritium in water samples was about $2 \mathrm{pCi} / \mathrm{ml}$, while that for detection of gamma activity was about $1 \mathrm{pCi} / \mathrm{ml}$. No radionuclides were detected in any water sample at or above the indicated thresholds.

\subsubsection{Milk Sampling}

Milk samples were collected at two locations: the Norell Ranch and the Rodriguez dairy southeast of Meeker. Samples were collected at about 
Table 8. Site air moisture and precipitation samples, first production testing.

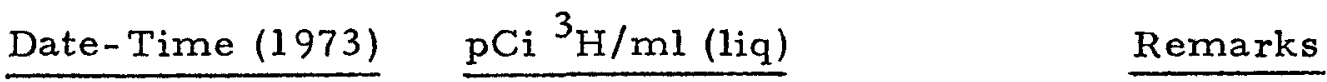

Air Moisture

Sept. 24 to

Nov 13 (37 samples) NDa

Nov. 13-14, 0800 ND

Nov. 14-15, 0800 ND

Nov. 15-16, $0800 \quad 5.6$

Nov. $16-17,0800 \quad 4.7$

Nov. $17-19,0800 \quad 5.0$

Nov. $19-20,0800 \quad 2.4$

Precipitation

Oct. 11, 1100 ND $\quad 150 \mathrm{ft} \mathrm{N}$ and S of flare stack

Nov. 4, ND

Nov. 19, $0200 \quad 25.2$

$150 \mathrm{ft} N$ and $S$ of flare stack

Nov. 19, 0225

36.8

Snow EW area

Nov. 19, $0930 \quad$ ND

Nov. 19, $0945 \quad$ ND

Snow flare stack area

$150 \mathrm{ft} N$ of flare stack

Nov. 19, $1000 \quad$ ND

$1000 \mathrm{ft}$ E of flare stack

Nov. 19, 1015 ND

$150 \mathrm{ft} W$ of flare stack

Nov. 19, $1030 \quad$ ND

Nov. 19, $1045 \quad$ ND

Nov. 19, $1100 \quad 50.7$

Nov. 19, 1115 ND

$1000 \mathrm{ft} N$ of flare stack

$1000 \mathrm{ft} W$ of flare stack

$150 \mathrm{ft} E$ of flare stack

$150 \mathrm{ft} S$ of flare stack

$1000 \mathrm{ft} S$ of flare stack

a ND means less than $\angle \mathrm{pCi} / \mathrm{ml}$. 


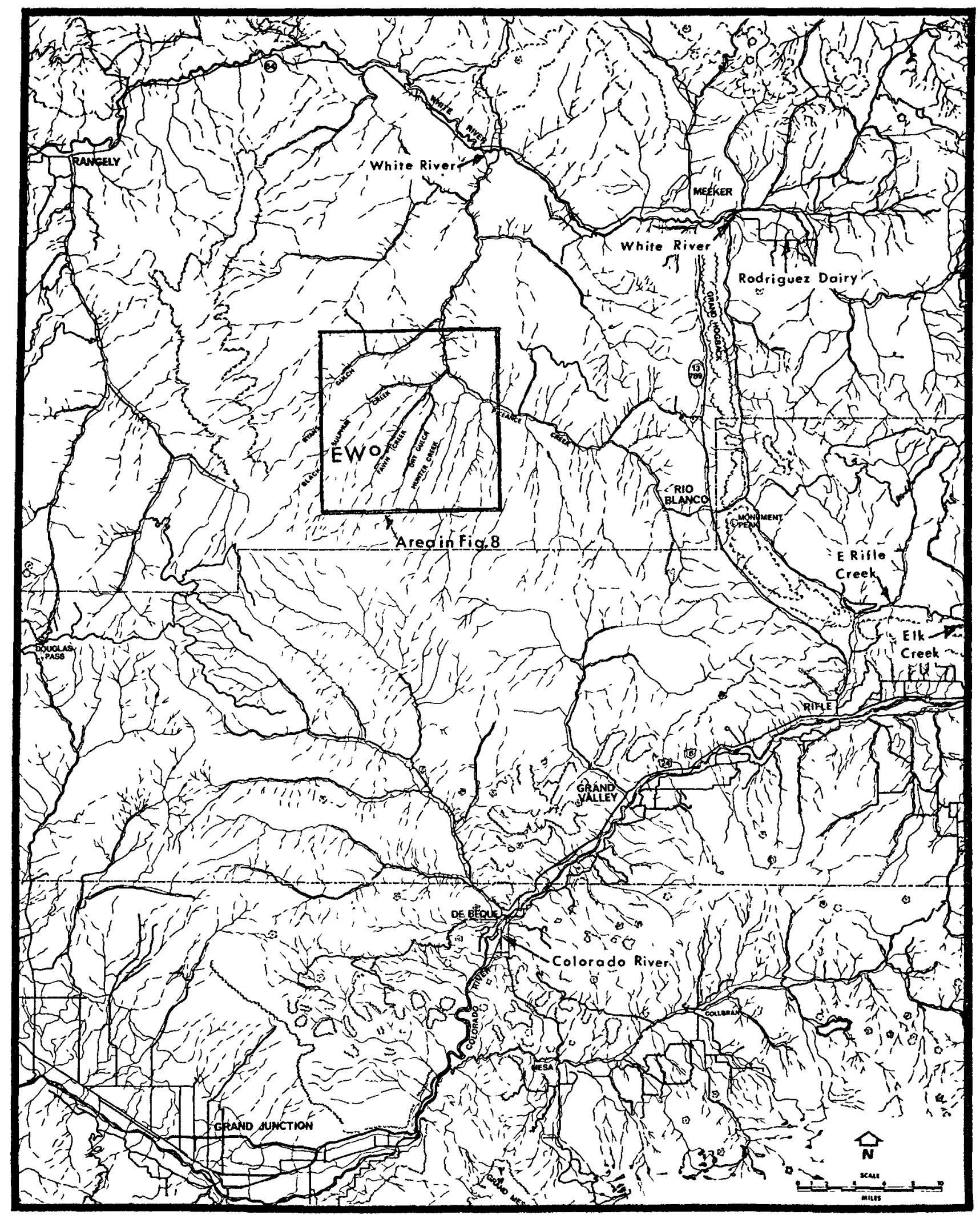

Figure 9. Distant environmental monitoring points - production testing. 
3-day intervals starting on November 6, 7, 1973 and ending on November 19, 20, 1973. Samples were assayed for tritium by distillation and liquid scintillation means and for gamma emitters.

The sensitivity for detection of tritium in milk samples was about $2 \mathrm{pCi} / \mathrm{ml}$, while that for detection of gamma activity was about $1 \mathrm{pCi} / \mathrm{ml}$. No radionuclides were detected in any milk sample at or above the indicated sensitivities except for naturally occurring $40_{\mathrm{K}}$.

5.1.6 Soil Sampling

Soil samples were collected on September 13, 14, 1973 (before reentry drilling) and again on November 22, 1973 (2 days after flaring stopped) at 7 locations: 1 in the emplacement well area, 2 within 120 feet of the base of the flare stack, and 4 in Fawn Creek valley, spaced from 2 miles upstream to 2 miles downstream.

The water was extracted from each sample and assayed for tritium by liquid scintillation means. The sensitivity for detection of tritium in recovered moisture was about $2 \mathrm{pCi} / \mathrm{ml}$. All soil sample analyses were below the indicated sensitivity except 2 samples collected on November 22, 1973 near the base of the flare stack. Concentrations measured were $28.0 \mathrm{pCi} / \mathrm{ml}$ and $25.7 \mathrm{pCi} / \mathrm{ml}$ for samples collected at points 70 feet south and 120 feet north of the flare stack, respectively.

\subsubsection{Vegetation and Milkcow Feed}

Samples of cattle fodder were collected at four locations (Figure 8): the Equity camp, and the Berthelson, Brennan, and Norell ranches. Samples of deer browse were collected at 6 locations: 2 within 120 feet of the flare stack, and 4 in Fawn Creek valley spaced from 2 miles upstream to 2 miles downstream. Samples were collected at all locations before the flaring on November 5, 1973, and after the flaring on November 22, 1973. All samples were assayed for ${ }^{89} \mathrm{Sr}$ and ${ }^{90} \mathrm{Sr}$. Those collected after the flaring were assayed for tritium in recovered moisture by liquid scintillation means and for other radionuclides by gamma scan.

No ${ }^{89} \mathrm{Sr}$ was detected in any sample, with a 2 -sigma sensitivity of $0.1 \mathrm{pCi} / \mathrm{g}$, dry weight. Analyses for ${ }^{90} \mathrm{Sr}$ ranged from $0.08 \pm 0.06$ to $0.51 \pm 0.26 \mathrm{pCi} / \mathrm{g}$ for the samples collected before the flaring and from $0.06 \pm 0.03$ to $0.46 \pm 0.06$ $\mathrm{pCi} / \mathrm{g}$ for the postflaring samples. Mean values were $0.29 \mathrm{pCi} / \mathrm{g}$ and 0.22 $\mathrm{pCi} / \mathrm{g}$, respectively. Analyses for tritium of the postflaring samples were not detectable with a 2 -sigma sensitivity of $2 \mathrm{pCi} / \mathrm{ml}$ of recovered moisture. Gamma scans of postflaring samples indicated no detectable activity above system background other than natural $40_{\mathrm{K}}$. 


\subsubsection{Bioassays}

Two urine samples were submitted by a ranchhand at the Norell Ranch, one each on November 15 and 16, 1973. Additionally, 192 urine samples were submitted before, during, and after the flaring by project participants. All urine samples were assayed for tritium by liquid scintillation means. No elevated levels of tritium were found with a detection sensitivity of $10 \mathrm{pCi} / \mathrm{ml}$.

\subsubsection{External Background Radiation}

Thermoluminescent dosimeters (TLD's) were exposed throughout the area at 16 locations as a part of the routine environmental monitoring for the project. These locations include the wellhead; 2 near the flarestack; 4 in Fawn Creek valley, spaced from 2 miles upstream to 2 miles downstream; the Equity camp; and the Berthelson, Brennan, and Norell ranches; and the cities of Grand Junction, Grand Valley, Meeker, Rangely, and Rifle. These TLD's were in the field from August 24, 1973 to November 29, 1973.

TLD readouts showed dose rates ranging from 1.9 to $4.2 \mathrm{mrem}$ per week with a mean of $2.8 \mathrm{mrem}$ per week for 15 locations. One T LD 2 miles upstream from the emplacement well was lost. These TLD data are in the same range as those measured in previous periods as given in the routine environmental monitoring reports collectively identified as Reference 9.

\section{2}

\section{SECOND PRODUCTION TESTING}

In connection with the second production testing, the routine environmental sampling program(8) was extended so as to terminate on July 31, 1974. The experience with off-site environmental sampling during the first production testing led to limitation of the augmented environmental sampling in connection with the second production testing primarily to water sampling at nearby locations and to precipitation and snow sampling near the flare stack. Some additional effort was expended on air moisture sampling, bioassays, and external radiation measurements in the immediate site vicinity.

\section{2 .1}

\section{Site Air Moisture Sampling}

Air moisture samplers (molysieve in a long mesh basket) were exposed at the site continually from January 26 to February 16, 1974 and changed at intervals of 1 to 2 days throughout the period. The 16 assays of recovered moisture for ${ }^{3} \mathrm{H}$ are shown in Table 9. It will be noted that the peak values occur during the first 4 or 5 days of flaring, when both the flow rates and ${ }^{3} \mathrm{H}$ concentrations were highest and that measurable values are infrequent thereafter. If the not detectable values are averaged in at $2 \mathrm{pCi} / \mathrm{ml}$, the mean for the 16 observations is $4.3 \mathrm{pCi} / \mathrm{ml}$, an upper limit. Considering only the water of combustion leaving the flare stack in burning a mixture 
of $60 \% \mathrm{CO}_{2}, 10 \% \mathrm{H}_{2}$, and $30 \% \mathrm{CH}_{4}$, about $9.4 \times 10^{8} \mathrm{ml}$ (liq) of water were released during the second production testing, with an ${ }^{3} \mathrm{H}$ content of 22.65 Ci. An additional $7.5 \times 10^{6} \mathrm{ml}$ (liq) were flared as water vapor with an ${ }^{3} \mathrm{H}$ content of $0.57 \mathrm{Ci}$. The average concentration of ${ }^{3} \mathrm{H}$ in the released water, was, then, about $25,000 \mathrm{pCi} / \mathrm{ml}$ (liq) and the observed dilution factor between the plume from the stack and the site was in the range of 1,500 to not less than 12,500 .

Table 9. Site air moisture samples, second production testing.

\begin{tabular}{lr} 
Date-Time (1974) & $\mathrm{pCi}^{3} \mathrm{H} / \mathrm{ml} \mathrm{M}$ \\
\hline & \\
January 26-28 & 4.3 \\
January 29-31 & 12.4 \\
January 31-February & 5.2 \\
February $1-2$ & 16.4 \\
February $2-3$ & 4.3 \\
February $3-5(1300)$ & $\mathrm{ND}$ \\
February $5(1300-1500)$ & $\mathrm{ND}$ \\
February $5-6$ & $\mathrm{ND}$ \\
February $6-7$ & 3.7 \\
February $7-8$ & $\mathrm{ND}$ \\
February $9-10$ & 2.6 \\
February $10-11$ & $\mathrm{ND}$ \\
February $11-12$ & $\mathrm{ND}$ \\
February $12-13$ & $\mathrm{ND}$ \\
February $14-15$ & $\mathrm{ND}$ \\
February $15-16$ & 3.9 \\
&
\end{tabular}

a ND means less than $2 \mathrm{pCi}^{3} \mathrm{H} / \mathrm{ml}$

5.2.2 Water Sampling

Water samples were collected daily from Fawn Creek at a point about 1 mile downstream from the site during the period January 28 to February 20, 1974. Well water samples were taken at about weekly intervals from January 30 to March 17, 1974. All samples were analyzed for tritium by liquid scintillation means with a detection sensitivity of $2 \mathrm{pCi} / \mathrm{ml}$. No detectable quantities of ${ }^{3} \mathrm{H}$ were found. Additional water samples were collected on March 29, 1974, at four locations (Figure 8): the Equity camp, and the Berthelson, Brennan, and iNorell ranches. These samples were analyzed by electrolytic enrichment and gas counting and were found to be in the range of $0.12 \pm 0.08$ to $0.25 \pm 0.08 \mathrm{pCi}^{3} \mathrm{H} / \mathrm{ml}$. These values are consistent with values previously reported $(9)$ for these sampling points. 
5.2.3 - Precipitation and Soils - Flare Stack Vicinity

Opportune samples of precipitation were collected near the flare stack during the second production testing. In addition, samples of soil and snow were collected after the end of flaring along four radials from the flare stack. All samples were analyzed for ${ }^{3} \mathrm{H}$ by liquid scintillation means. The results are shown in Table 10. The results of the area survey are also plotted in Figure 10 .

\section{2. $\quad$ Bioassays}

Project personnel handling or controlling the handling of tritiated liquids provided EIC with a urine sample before flaring and after completion of the injection of tritiated water into the Fawn Creek Government No. 1 disposal well. Thirty-two samples were analyzed for ${ }^{3} \mathrm{H}$ by liquid scintillation means with a sensitivity of $10 \mathrm{pCi} . \mathrm{ml}$. No elevated levels of tritium were found with a detection sensitivity of $10 \mathrm{pCi} / \mathrm{ml}$. No bioassays were performed for non-project-related persons.

\subsubsection{External Background Radiation}

Thermoluminescent dosimeters (TLD's) were exposed throughout the area at 16 locations as a part of the routine environmental monitoring for the project. These locations include the wellhead; 2 near the flare stack; 4 in Fawn Creek valley spaced from 2 miles upstream to 2 miles downstream; the Equity camp, and the Berthelson, Brennan, and Norell ranches; and the cities of Grand Junction, Grand Valley, Meeker, Rangely, and Rifle. TLD's were in the field from November 29, 1973 to June 1, 1974, and were changed on February 4, 1974. Readout of the TLD's showed dose rates ranging from 2.6 to $4.4 \mathrm{mrem}$ per week for the first set and from 2.6 to $3.5 \mathrm{mrem}$ per week for the second set. Both sets had a mean value of 3.1 mrem per week. These TLD data are in the same range as those measured in previous periods as given in the routine monitoring reports.collectively identified as Reference 9. 
Table 10. ${ }^{3} \mathrm{H}$ concentrations in precipitation and soils near flare stack, second production testing.

Date (1974)

January 29

February 6

February 6

February 6

February 6

February 7

February 7

February 7

February 7

February 15-16

February 15-16

February 15-16

February 15-16

February 15-16

February 15-16

February 15-16

February 15-16

February 15-16

February 15-16

February 15-16

February 15-16

February 15-16

February 15-16

February 15-16

February 15-16

February 15-16

February 15-16

February 15-16

February 15-16

February 15-16

February 15-16

February 15-16

\section{$\mathrm{pCi}^{3} \mathrm{H} / \mathrm{ml}$ Sample}

NDa

24.6

27.2

4.3

14.8

ND

7. 5

$\mathrm{ND}$

8.2

21.0

3.8

2. 7

4.3

ND

ND

ND

38.9

7.5

4.6

5. 1

ND

71.9

2. 0

ND

2. 5

6.6

102.3

19.0

17.1

11.2

10.2

3.6
Snow

Snow/rain

Snow/rain

Sn ow rain

Snow/rain

Snow

Snow

Snow

Snow

Soil

Soil

Soil

Soil

Snow

Soil

Snow

Soil

Soil

Soil

Soil

Snow

Soil

Soil

Soil

Soil

Soil

Soil

Soil

Soil

Soil

Soil

Snow

Direction and Distance $\frac{\text { From Flare Stack in Feet }}{\mathrm{N}} \mathrm{E}$ W

50

150

100

85

150

100

85

90

0

78

150

200

200

250

250

58

100

150

200

200
90

85

10

50

85

135

185
10

65

90

140

190

190

a ND means less than $2 \mathrm{pCi}^{3} \mathrm{H} / \mathrm{ml}$ 


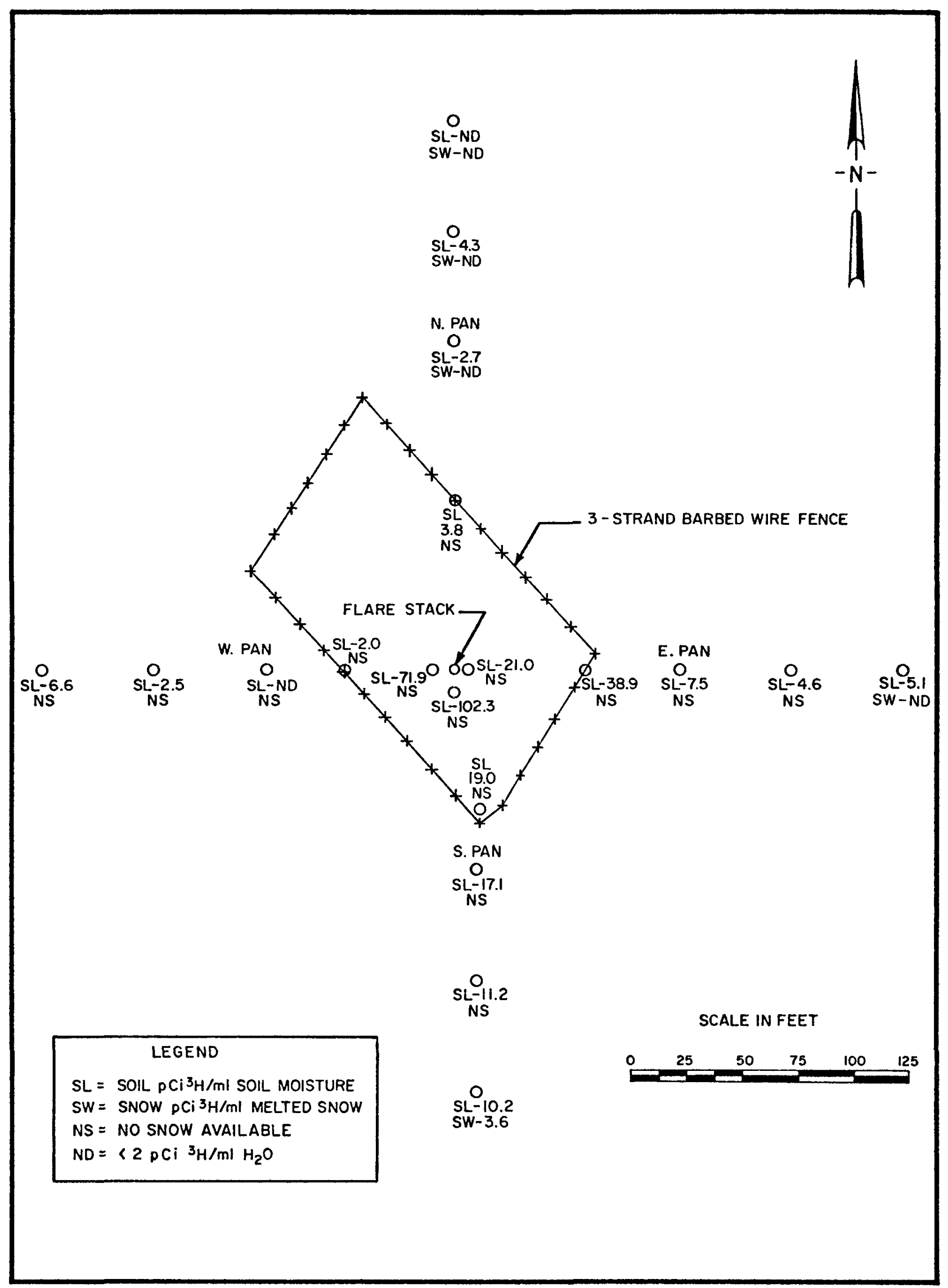

Figure 10. ${ }^{3} \mathrm{H}$ analysis results, Feb. 15, 16, 1974, vicinity of flare stack. $-35-)$ 


\section{REFERENCES}

1. "Permit for Subsurface Disposal", Colorado Water Quality Control Division, Colorado Department of Health, November 9, 1973.

2. "Project Rio Blanco, Subsurface Water Disposal Application", Continental Oil Company, June 18, 1974.

3. Perry's Chemical Engineers Handbook, Fourth Edition, McGraw-Hill, 1963, p. 4-68.

4. Dodge, B. F., Chemical Engineering Thermodynamics, McGraw-Hill, 1944, p. 200.

5. Katz, D. L. , et al., Handbook of Natural Gas Engineering, McGraw-Hill, 1959, p. 335.

6. Smith, C. F., "Rio Blanco Gas Composition, LLL Data Summary, Calibration and Production Testing of RB-E-01", UCID-16579, Lawrence Livermore Laboratory, August 15, 1974.

7. Private Communication with C. F. Smith, Lawrence Livermore Laboratory, February 25, 1975.

8. "Project Rio Blanco Definition Plan, Vols. II and III", CER Geonuclear Corporation, January 24, 1973.

9. "Radiological Monitoring Program, Project Rio Blanco", reported to CER Geonuclear Corporation by Eberline Instrument Corporation, PNE-RB-51-10, inclusive. 